\title{
Carbon Materials as Catalysts
}

\author{
Seongyop Lim, ${ }^{1}$ Doohwan Jung, ${ }^{1}$ Seong-Ho Yoon $^{2, \uparrow}$ and Isao Mochida ${ }^{2}$ \\ ${ }^{1}$ Advanced Fuel Cell Research Center, Korea Institute of Energy Research, 71-2 Jang-dong, Yuseong-gu, Daejeon 305-343, Korea \\ ${ }^{2}$ Institute for Materials Chemistry and Engineering, Kyushu University, 6-1 Kasugakoen, Kasuga, Fukuoka 816-8580, Japan \\ ‘e-mail: yoon@asem.kyushu-u.ac.jp \\ (Received February 4, 2008; Accepted March 10, 2008)
}

\begin{abstract}
Understanding the exact structure and surface characteristics of carbon materials is very important for design, synthesis, and utilization of the best carbon form with particular functions and high performance for practical applications such as selective adsorption adsorbents, energy storage materials, catalysts or catalyst supports, etc. This review paper focuses on carbon surface properties and the interaction between gaseous or liquid substances and carbon surface. Catalytic functions of carbon materials are reviewed including recent progress in synthesis and applications of nano-carbons.
\end{abstract}

Keywords : Carbon catalysts, Catalyst supports, Adsorption, Surface properties

\section{1. 서 론}

탄소는 불의 발견으로부터 시작하여 비교적 단순한 기능이 지만 오랜 인류의 역사에서 중요한 역할을 하여 왔다[1]. 20세 기에 이르러 숯과 석탄의 연료로서의 기능을 넘어 고급 기능 성 공업재료로서 제철제강, 자동차, 항공기, 건설 등 산업기술 에서 차지하는 비중은 이루 말할 수 없이 확대되고 있다[2]. 또한, 21 세기의 문턱에서 시작된 탄소나노튜브(carbon nanotube)에 대한 폭발적인 관심은, 그간 한국에서 다소 경시되었 던 탄소재료에 대한 흥미를 불러일으키는 계기가 되었다.

탄소는 다양한 형태 및 구조, 우수한 주형성 혹은 성형성과 더불어, 높은 비표면적, 화학적 물리적 표면 개질(surface modification)과 세공 부가기능의 특이한 성질에 의해, 우수한 흡착기능에 따른 촉매 및 촉매 담지체로서의 기능을 나타낼 수 있다. 탄소표면촉매 및 금속 담지 탄소촉매는, 배연탈황 및 탈질, 가스분리 및 정제, 방향족 화합물의 수소화, 석유탈황, 탈질 및 탈금속, 그리고 고도의 석탄가스화 및 액화에 이르기 까지 고효율의 촉매기능을 발휘하고 있다.

풀러렌(fullerene)의 발견으로부터 시작된 다양한 나노탄소 의 합성 및 구조연구에 의해, 기존의 카본블랙 등의 탄소재료 에 비하여 규칙적이고 균일한 표면구조를 지닌 나노탄소를 제 조할 수 있고, 나노미터 수준에서 구조의 제어가 가능하게 되 어, 탄소를 이용한 촉매의 기능 향상 및 신기능 창출의 효과 가 더욱 기대되고 있다.

본 소론에서는 탄소재료의 특성 중에서 중요한 표면 특성에 기초하여, 탄소재료의 촉매 기능에 대하여 조명하고자 한다. 기존 탄소재료를 촉매 및 촉매 담지체 기능의 측면에서 설명 하고 최근의 나노탄소와 나노구조의 개념을 이용한 촉매기능
을 요약하였다.

\section{2. 표면기능성 탄소재료의 분류}

탄소의 표면이용은, 흡착 $[3,4]$, 촉매 $[5,6]$, 열전달(나노유체) $[7,8]$, 에너지 저장 $[9,10]$, 전기화학 반응 기능(전지 및 표면 처리)[11], 전자기반응기능(전기점성유체)[12, 13] 등 다양하게 진행되고 있다. 이용 대상 표면도 다양한 종류가 있어, 최근의 나노개념을 적용하여 분류하면 다음과 같다.

1) 나노공간탄소(다공성 탄소, porous carbons) : 활성탄[1], 활성 탄소섬유 $[1,14]$, 메조기공탄소 $[15,16]$

2) 나노상탄소(나노탄소, nano-sized carbons) : 섬유상 나노 탄소, 즉 탄소나노섬유(carbon nanofibers, CNF)[17, 18] 및 탄 소나노튜브(Carbon nanotubes, CNT)[19], 입자상 나노탄소, 즉 나노혼(nano-horn)[20], 풀러렌[21], 자이언트 풀러렌(giant fullerenes)[22], 탄소 나노오니언(carbon nano-onion)[23], 카본 에어로졸(carbon aerosol)[24], 카본블랙(carbon black)[25], 블 랙 카본(black carbon, particulate matter)[26] 등

3) 나노구조탄소(nano-structured carbons): 인조흑연[27], 탄 소섬유(carbon fiber)[14], 글래시탄소(glassy carbon)[28]

4) 초구조탄소(super-structured carbons) : HOPG (highly oriented pyrolytic graphite) [29], 천연흑연[29]

나노공간탄소는, $50 \mathrm{~nm}$ 이하의 균일한 나노공간(nano-space) 이 비교적 규칙적으로 형성된 벌크 및 입상 탄소구조를 의미 한다. 구체적으로, 전구체(precursor) 또는 탄화체의 부분가스 화(활성화 혹은 부활)에 의해서 형성되는 슬릿형(slit type) 입 자 내 나노공간(intra-particle pore nucleation)을 주로 지닌 탄 


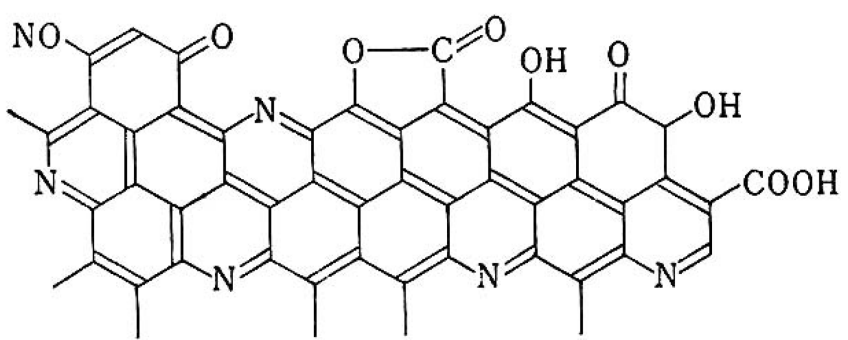

Fig. 1. Molecular structural model of PAN-based activated carbon fibers [1].

소재료로 활성탄 또는 활성탄소섬유 등을 들 수 있다. 한편, 나노입자의 집합(aggregation) 및 괴상(coagulum)의 형성으로 유도되는 입자간 나노공간의 유도(inter-particle pore nucleation)에 의해 형성된 탄소재료로는 카본블랙 및 카본에어로졸 등을 들 수 있다. 메조기공이 $80-90 \%$ 이상의 비중을 차지하 는 메조기공 탄소는 입자간 집합이 템플레이트(template)에 의 해 독특한 형태로 유도된 기공을 지닌 탄소물질로 정의될 수 있다.

나노공간탄소는 다량의 나노공간에 의한 고비표면적을 이용 하는 기능성 탄소재료다. 나노공간탄소의 표면은 기본적으로 활성화법에 의해 형성되기 때문에 통상 Fig. 1 [1]과 같이 다 양한 산화기능기(oxygen functional groups)를 지닌 것으로 표 현이 되고 (특히, 활성탄 및 활성탄소섬유), 제조법에 따라서 나노공간의 형태와 표면 특성을 다양하게 제어할 수 있다[3]. Fig. 2 [31]는 활성탄 및 활성탄소섬유로 대표되는 나노공간탄 소(다공성 탄소) 의 구조를 기체 등온 흡착 곡선과 기공 분포 를 통하여 파악한 결과를 모식적으로 나타낸 것이다. 활성탄 소섬유의 마이크로 기공은 대부분 외부로 드러난, 다소 단순 한 형태인 반면, 활성탄의 경우는 2 차, 3 차 구조의 복잡한 기 공 구조를 가지는 것으로 알려져 있다.

나노상탄소는, 풀러렌으로 대표되는 입상 나노탄소와 탄소 나노튜브와 같은 섬유상 나노탄소로도 구별할 수 있으며, $50 \mathrm{~nm}$ 이하 크기의 1차원 혹은 2차원 탄소로서 알려져 있다. 탄소나노튜브 및 탄소나노섬유와 같은 섬유상 나노탄소는 기 존의 탄소섬유와 직경의 크기가 다를 뿐만 아니라 비교적 결 정성 우수하고 표면 및 미세 구조가 상당히 균일하다는 특징 을 지닌다. 입상의 나노탄소 중에서 자이언트 풀러렌과 나노 오니언은 균일한 구조의 비교적 높은 흑연화도를 나타내는 반 면, 카본에어로졸, 카본블랙 및 블랙카본은 대부분 흑연화도가 낮다. 특히, 블랙카본(바이오매스 또는 화석연료의 자연발화에

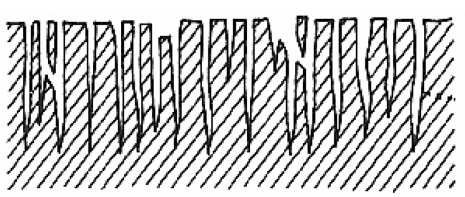

활성탄소섬유 Activated Carbon Fibers

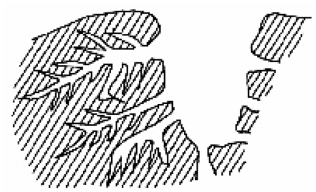

입상 활성탄 Activated Carbons
Fig. 2. Surface Pore Structure of Activated Carbon Fibers and Activated Carbons [31].
서 생성되는 탄소질의 생성물, 공업적으로 제조하는 카본블랙 과 구분함)은 기상 및 액상으로부터 형성된 탄소가 혼합된 불 규칙한 구조를 지닌다.

입상 나노탄소 및 그 집합체는 섬유상 나노탄소에 비하여 비교적 자유표면(free surface)이 많고, 금속입자의 안정한 표 면분산 및 포착(anchoring) 이 가능한 2차 구조(secondary structure)를 지니고 있어, 카본블랙과 같이 불균질 촉매(heterogeneous catalysts)의 담지체로 사용되는 경우가 많다.

나노구조탄소(nano-structural carbon)은, 인조흑연입자, 탄소 섬유 및 글래시 탄소 등이 알려져 있다. 탄소는 유기물을 열처 리하여 생성되는 유일한 무기물이다. 고분자 등의 유기물은, 물 질 유래의 기본 구조단위(domain)로 구성되어 있어 탄화 열처 리 과정에서 이런 기본 구조 단위가 독립적 혹은 상호간의 영 향에 의해 변형 연계됨으로써, 나노구조의 탄소체가 형성된다 $[32,33]$. 인조흑연은, 다양한 원료 유기물과 그들의 적합한 열 처리 과정의 선택에 의해, 광범위한 형태 및 흑연화도의 선택 이 가능하며, 다양한 표면과 물성을 유도할 수 있다. Fig. 3에 는 나노구조탄소의 탄화 열처리 단계에 의한 단위구조의 형성 기구를 모식적으로 나타내었다 $[1,33]$. 기체, 액체, 고체 각각 다른 상의 전구체는 탄화 과정을 거치면서, 열분해 되고 재배 열되지만, 생성물인 탄소재료의 구조 특성은 근본적으로 전구 체의 특성에 기초하고 있다. 마이크로 도메인, 도메인, 벌크 구 조로 이어지는 계통적인 탄소구조에 대한 인식은, 특정한 전 구체로부터 각 열처리 및 탄화 단계를 거쳐 형성되는 탄소재 료의 특성을 파악하는데 상당히 중요하다.

초구조탄소(super-structural carbon)는 흑연단결정에 가까운 구조를 지니며, 나노구조탄소에서 언급한 구조단위를 지니지 않는 천연흑연, 키시흑연(kish graphite) 및 $\mathrm{HOPG}$ 와 같은 독 특한 인조흑연재료다. 키시흑연은 철의 제강과정에서 철용탕 에 부유 형성되지만, $\mathrm{HOPG}$ 는 이흑연화성 (graphitizable) 기상 탄소입자 혹은 위스커(whisker)를 고온에서 HIP (hot isostactic pressing) 하여 탄화 성형한 후, $3400^{\circ} \mathrm{C}$ 이상의 고온 열처리함 으로써 형성된다. 초구조탄소는 주로 고흑연화도 표면이 요구 되는 촉매 응용 등에 사용된다.

\section{3. 표면기능성 탄소의 제조}

\section{1. 나노공간탄소의 제조}

활성탄과 활성탄소섬유와 같은 다공성 탄소는, 전구체 또는 원료탄소의 선정, 부형(賦型), 전처리 및 안정화, 탄화, 활성화 (또는 부활 賦活), 표면처리, 나아가서는 성형에 의해 제조된 다. 다양한 원료의 선택으로 더욱 다양한 조성 및 물성을 지 닌 나노공간탄소를 제조할 수 있다. 고비표면적을 달성하기 위 한 부활(활성화, activation) 과정은, 일반적으로 물 혹은 이산 화탄소에 의한 부분 가스화가 사용된다[3]. 수산화칼륨 혹은 수산화나트륨 등 알칼리염을 이용한 활성화를 적용하면, 더 높 


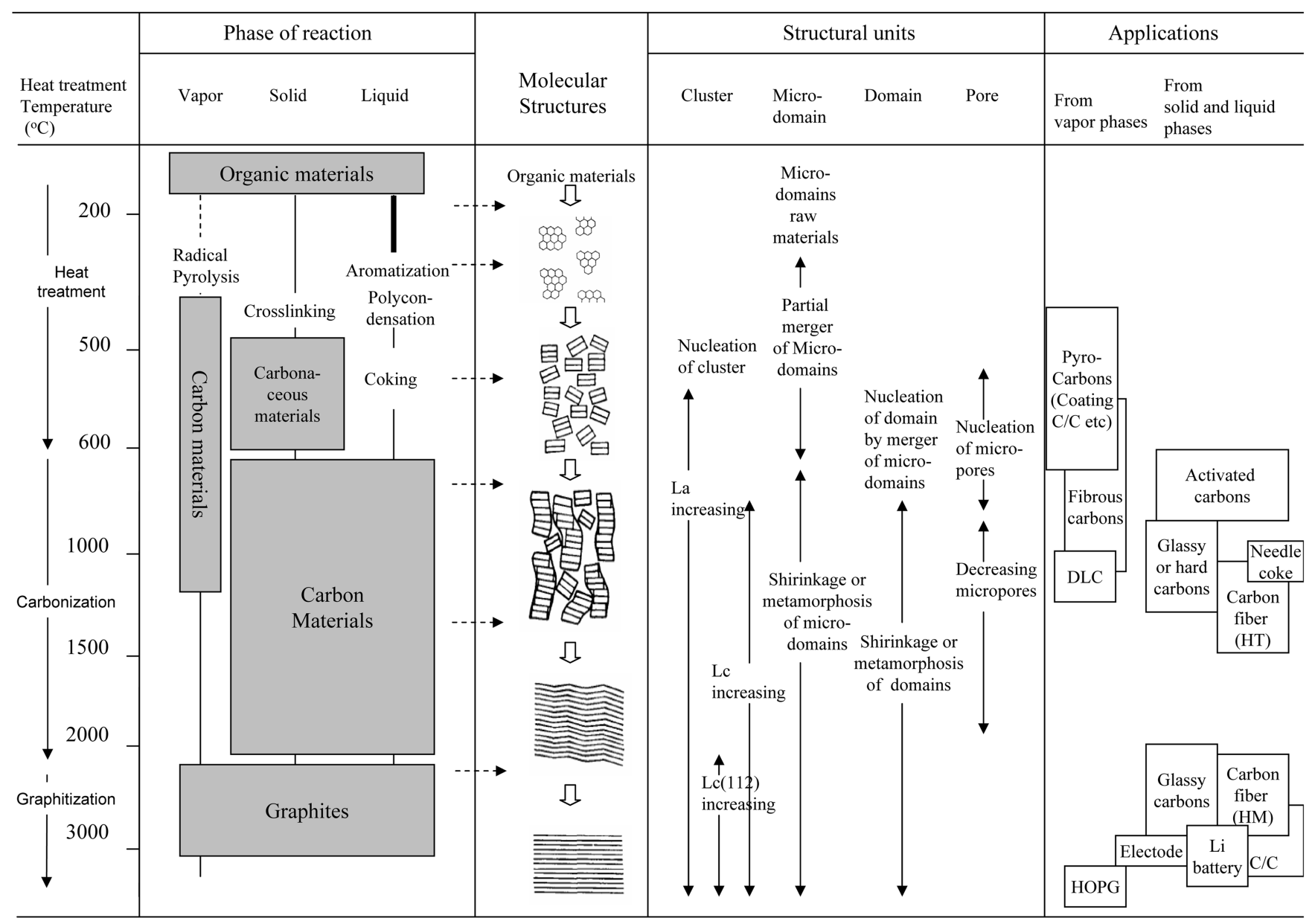

Fig. 3. Formation mechanism, relating structural changes, and produced carbon forms of nanostructured carbons from various phase precursors according to the temperature $[1,33]$.

은 비표면적 $\left(2,000 ~ 3,000 \mathrm{~m}^{2} / \mathrm{g}\right)$ 을 얻을 수 있다[3]. 산화기능 기를 다량 도입하기 위해서는 $\mathrm{HNO}_{3}, \mathrm{H}_{2} \mathrm{SO}_{4}$ 등 산화제에 의 한 저온 습식처리가 가장 일반적으로 이용되지만, 최근에는 나 노상 탄소의 구조 파괴를 최소화하여 구조적 기능을 저하를 방지하고 표면만을 선택적으로 산화하기 위해서 전기화학적 산화 방법 등도 개발되고 있다[34].

메조기공탄소는, 고분자 혹은 단량체를 메조기공을 지닌 세 라믹 주형(템플레이트)에 주입하여 탄화 열처리한 후, 산 및 알칼리 처리에 의해 세라믹 주형을 제거함으로써 제조하는 템 플레이트법(주형법, template method)[15]과 나노크기의 세라 믹 입자를 유기계 전구체에 혼련시킨 후, 적절한 온도에서 탄 화 열처리한 후, 산 및 알칼리를 사용하여 세라믹 나노입자를 제거함으로써 제조하는 동적 주형법(movable template method)[35, 36]이 일반적으로 알려져 있다. 최근에는 특성이 상이 한 고분자를 적절한 혼합하여 나노공간탄소 및 나노상탄소를 제조하는 기술과[37], Fig. 4에 보이는 바와 같이, 탄소나노섬 유의 표면에 나노크기의 금속입자를 분산시킨 후, 이를 부분 가스화 처리함으로써 메조기공을 지닌 섬유상 나노탄소를 제
조하는 방법 등도 보고된 바 있다[38].

\section{2. 나노상 탄소의 제조}

플러렌과 탄소나노튜브는, 최초에는 탄소아크법에 의해 제 조되었으나, 그 후 대량 합성이 가능한 더 경제적인 방법이 개 발되어 왔다. 플러렌은 연소법과 고분자 나노입자의 직접 탄 화법으로 단위 생산량을 상당히 개선하였다 $[39,40]$. 탄소나노 튜브는 주로 일산화탄소 및 탄화수소가스를 원료로 사용하거 나 벤젠, 톨루엔 등의 액체 원료로부터 $350 \sim 1200^{\circ} \mathrm{C}$ 에서 천이 금속계 촉매상 열분해 및 성장에 의해 생성시키는 촉매성장법 에 의해 대량제조가 가능해졌다[41]. 탄소나노섬유는 탄소나 노튜브와 유사한 촉매성장법에 의해 주로 제조되지만 $[17,18]$, 촉매종류 및 가스의 선택에 의해 다양한 조직 및 표면을 제어 할 수 있으며, 탄소나노튜브에 필적하는 극세상 탄소나노섬유 의 제조도 가능하게 되었다[42, 43].

고비표면적을 지닌 카본에어로졸은 열경화성 수지의 나노 입자를 탄화하여 제조한다[24]. 카본에어로졸은 탄화 과정에 

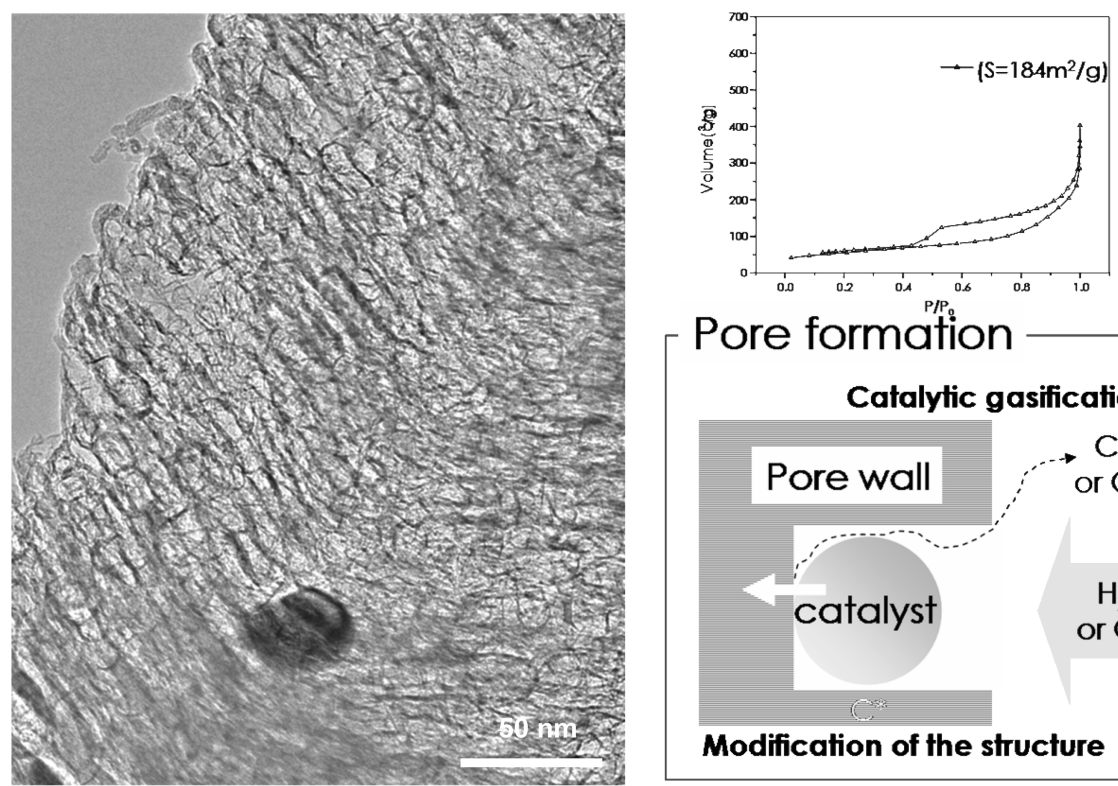

Pore formation

Catalytic gasification

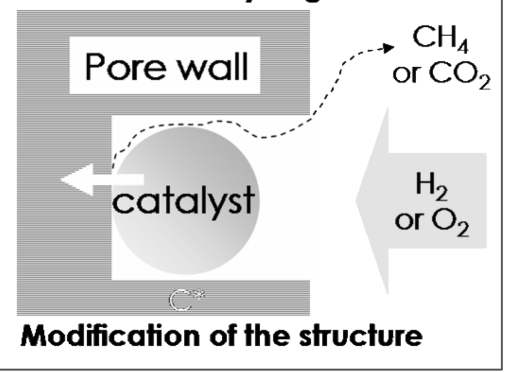

Fig. 4. A TEM image of mesoporous carbon nanofibers with a herringbone structure, the nitrogen adsorption isotherm, and suggested formation mechanism [38].

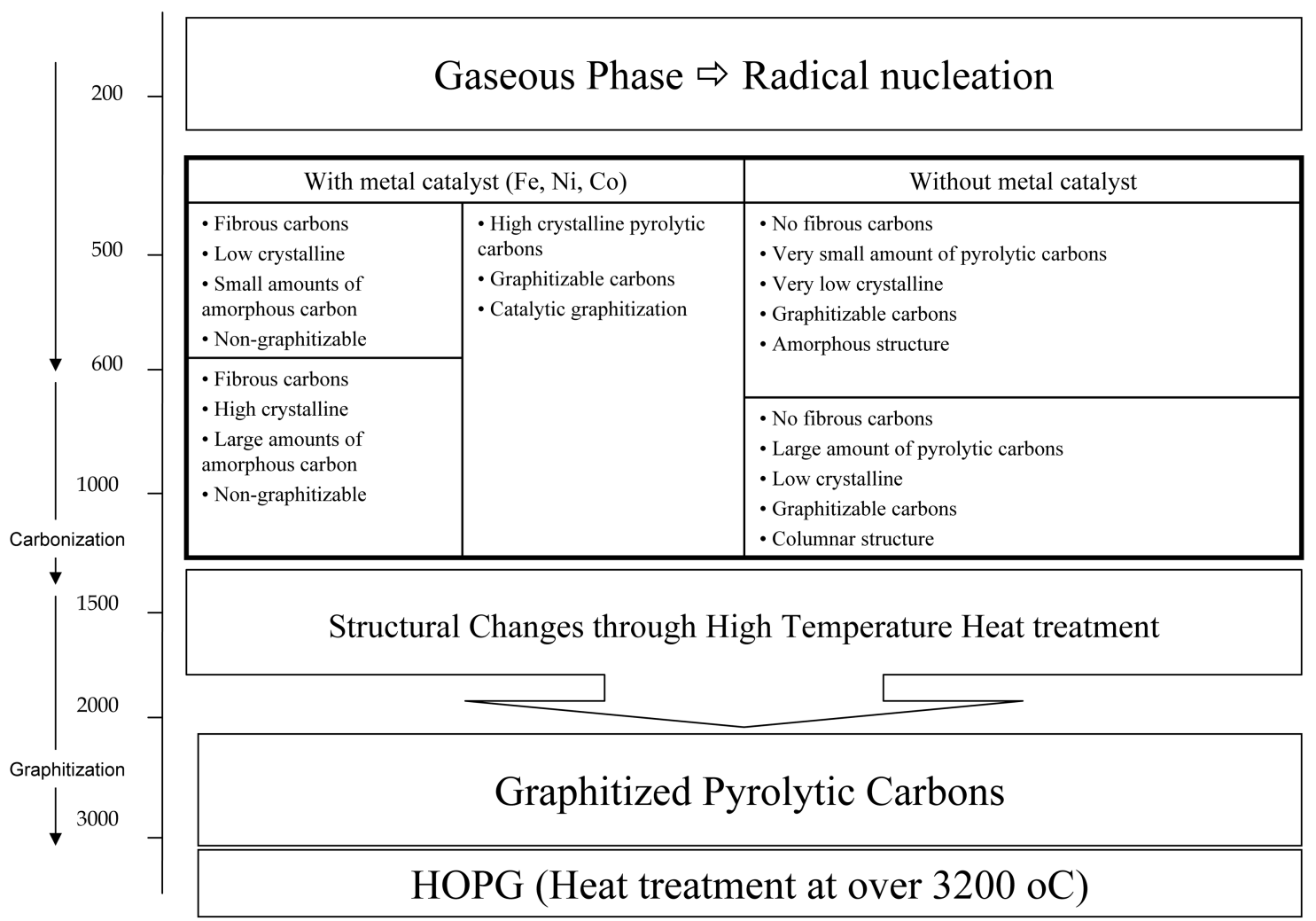

Fig. 5. Vapor phase carbonization.

서 초나노입자 상호간의 집합 및 괴상 형성에 의해 입자간의 나노공간의 유도에 의해 생성되는 다공성 탄소로서 메조기공 의 비율이 높은 편이다. 현시점에서 제조 비용이 많이 드는 편
이지만, 향후 원료선택, 탄화수율의 향상 등 제조공정의 개선 에 의해 제조 비용의 저하를 기대할 수 있다. Fig. 5에 기상 탄 화기구를 모식적으로 나타내고 있다. 금속촉매가 있는 경우와 


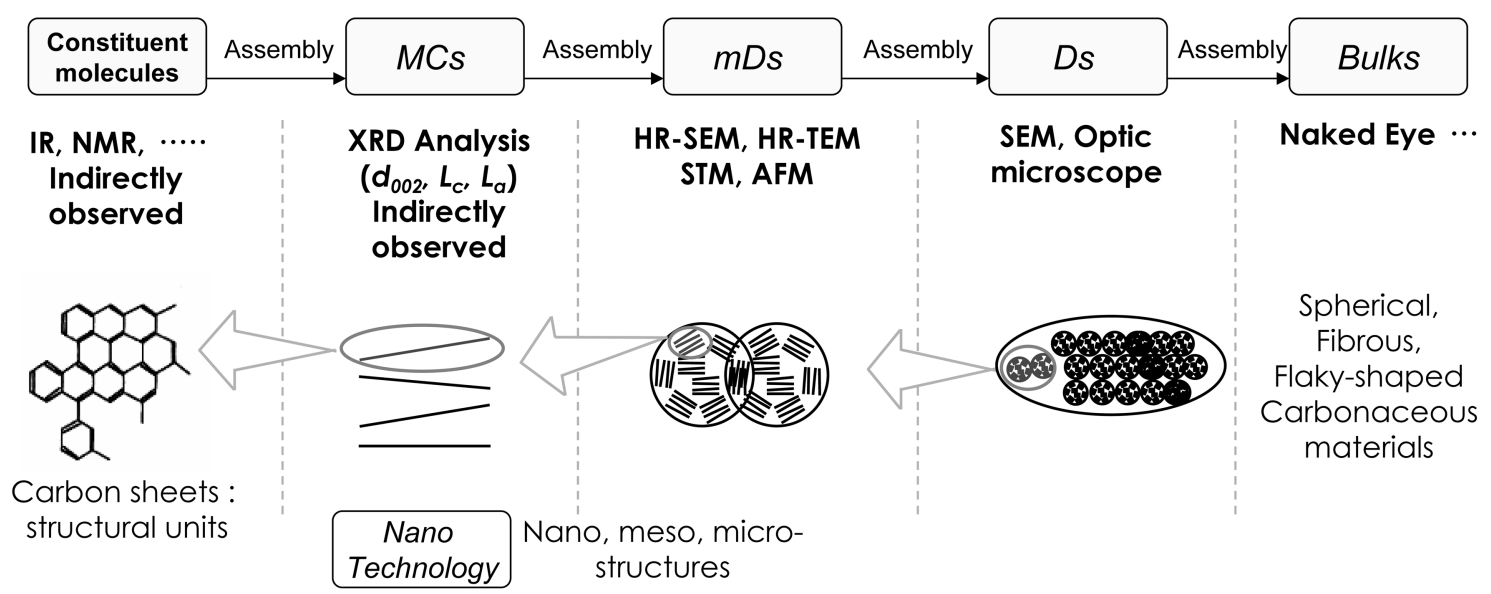

Fig. 6. Suggestive mechanism of liquid phase carbonization: orgainic molecules $\rightarrow$ micro carbons (MCs) $\rightarrow$ micro domains (mDs) $\rightarrow$ domains (Ds) $\rightarrow$ Bulk carbons.

없는 경우에 생성되는 탄소물질은 형상 및 결정성이 다르다 [44]. 고온가압 성형 후 $3200^{\circ} \mathrm{C}$ 이상의 초고온 열처리를 거치 면 $\mathrm{HOPG}$ 를 제조할 수 있다.

카본블랙은 솣검정과 유사한 물질로서, 원료의 미세 액적(液 滴)이 부분 산화적인 분위기에서 급속히 불완전 연소하는 과정에서 생성된다[25]. 원료의 선정, 연소방식과 온도 및 냉 각조건 등에 의해 생성되는 카본블랙의 단위입자의 입경(mean particle size), 입자쇄 구조(particle-chain structure)가 결정된다. 산화분위기에서의 부분산화 혹은 환원 혹은 진공분위기 하에 서 흑연화 열처리를 하는 동안, 내부가 비어진 중공구조가 형 성된다. 형성된 카본블랙은 불활성분위기 하의 재열처리에 의 해 산소기능기의 탄소육각망면에의 부착량 및 기능기의 변형 이 제어 가능하다. 아세틸렌을 원료로 사용하는 아세칠렌블랙 은 $1800^{\circ} \mathrm{C}$ 부근에서 아세틸렌을 불활성 분위기하에 열분해 처 리하여 제조되는 것으로, 원료가 비교적 순수하여 생성물의 불 순물이 적고 결정성이 좋으며 전기전도도가 우수한 편이다 [45].

\section{3. 나노구조탄소}

인조흑연은, 이흑연화성 원료인 피치원료를 액상탄화하는 과정에서 형성되는 침상코크스(needle coke)[46] 등의 이흑 연화성 코크스와 피치류의 바인더를 혼련한 후, $2400^{\circ} \mathrm{C}$ 이상 의 고온 열처리하여 제조한다[27]. 제강공정에서 주로 사용하 는 흑연전극이 대표적인 인조흑연이다. 흑연화처리까지 한 피 치계 고성능 탄소섬유(mesophase pitch based high performance carbon fiber)도 중요한 인조흑연 중에 하나이다. 글래시탄소는, 주로 열경화 수지를 $800^{\circ} \mathrm{C}$ 이상의 온도에서 탄화 열처리하여 제조한다[47]. Fig. 6에는 유기물 유래의 마이크로 도메인 및 도메인 형성을 거치는 액상탄화기구를 모식적으로 나타내고 있다.

\section{4. 탄소의 표면 기공 구조의 파악}

나노공간탄소의 대표적 물질인 활성탄은, 탄소질의 충전상 과 공간상으로 구성되며, 충전상과 공간상과의 계면이 기능을 발현하는 표면으로 작용한다. 이 계면 중, 충전상에 의해 둘러 싸인 공간상은 세공으로 인식되며, 탄소 내부에 또 다른 표면 을 전개하는 형태로 인식할 수 있다. 한편, 미세입자 및 미세 섬유의 외부 표면도 다른 특성을 지닌 흡착기질의 수용 및 유 지에 대해 세공과 유사한 대상으로 작용 가능하다. 활성탄은 $100 \sim 3000 \mathrm{~m}^{2} / \mathrm{g}$ 의 표면적을 나타내며, 표면적의 대부분은 세 공에 의한 미세세공의 벽에서 제공되지만, 입자 및 섬유의 크 기가 극도로 작을 경우, 외부표면의 기여도가 커지게 되어 세 공과는 다른 비교적 고비표면적의 자유표면을 제공한다. 최근, 나노입자, 나노섬유 등 미세한 크기를 지닌 탄소의 표면기능 을 고려하면, 이들에 의해 형성되는 외부표면의 기여는 새로 운 기능 창출이 가능한 새로운 재료로 기대된다.

"탄소"구조를 분자, 나노, 메조, 및 마크로 단위의 시점에서 파악하는 개념이 최근에 진행되고 있다. 이런 구조개념은 활 성탄소의 기공 형성기구 및 생성 기공의 형태 등을 파악하는 데 있어서도 중요하다. 즉, 분자로서 탄소육각망면, 적층구조 로서 클러스터, 단위구조로서 마이크로 도메인 및 도메인으로 탄소구조의 구조를 계층적 구조발달 측면(hierarchy of carbon structure)에서 표현 할 수 있다. Fig. 7에 피치계 탄소섬유의 형성 과정과 관련된 일례를 나타내었다[48]. 계층적 구조 관점 에서 파악할 때, 탄소의 공간상은 단위 입자 자체에 형성된 기 공(intra-particle pores)과 단위 입자간에 형성된 공간(interparticle space)로 분류할 수 있다.

활성탄의 세공의 경우, 세공의 직경 및 세공입구의 형태에 의해 흡착질의 침투여부가 결정되며 또한 흡착속도도 결정된 다. 세공크기는 IUPAC(international union of pure and applied chemistry)에서 추천하는 바에 따라서 micropore: $2.0 \mathrm{~nm}$ 이하, mesopore: $2.0 \sim 50 \mathrm{~nm}$, macropore: $>50 \mathrm{~nm}$ 로 분류할 수 있고, 


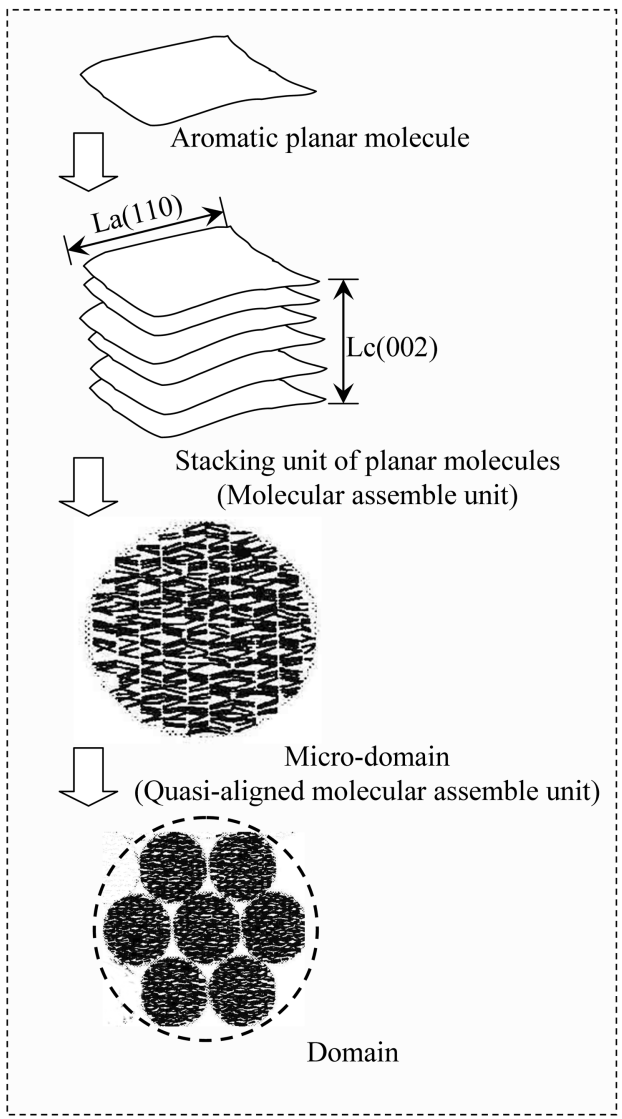

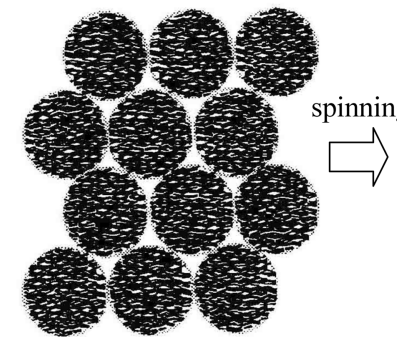

Closely packed micro-domains in mesophase pitch

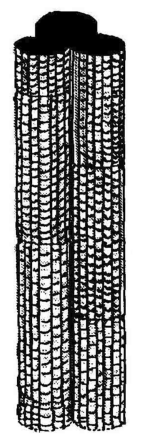

Pitch fiber

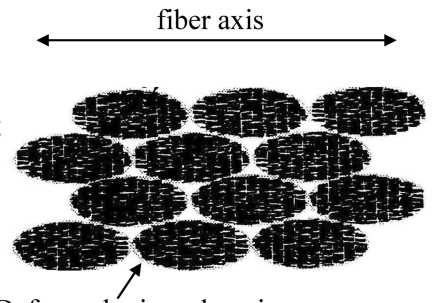

Deformed micro-domain

Aligned micro-domains in the mesophase pitch fiber

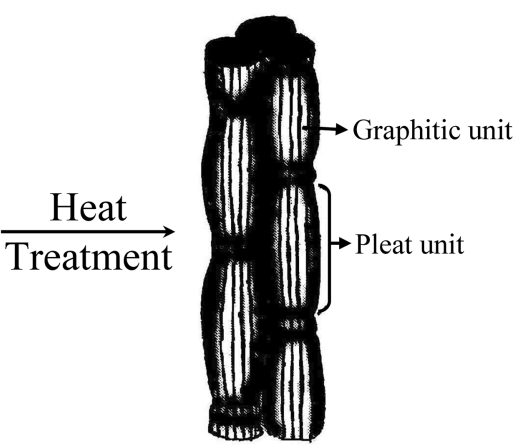

Graphitized fiber

Fig. 7. Structural hierarchy of pitch-based carbon fibers based on the micro domain concept [48].

최근 진공기술 및 측정법의 발달과 함께 가능해진 극히 미세 한 세공 (sub-micropore $<0.8 \mathrm{~nm}$ )의 해석 및 기능의 중요성 등 도 종종 언급된다[30, 49]. 큰 표면적을 달성하기 위해서는 미 세기공의 비율이 중요하지만, 물질의 출입이 비교적 원활하고 나노미터 크기의 거대 흡착질에 대한 빠른 흡착 기능을 지닌 메조기공의 창출도 최근에는 많은 주목을 받고 있다.

입상 활성탄은 Fig. 2에 나타낸 바와 같이, 입자 표면에서 내부 방향으로 대기공, 중기공, 소기공이 연결되어 형성되며, 이런 현상은 표면적이 높을수록 또한 입자가 클수록 강조되어 나타난다. 한편, 섬유상 탄소의 섬경이 작을수록, 외부 표면만 의 적절한 가스화가 진행되면 얕고 균일한 소기공을 선택적으 로 도입할 수 있다. 활성화율을 낮게 할수록 얻어지는 활성탄 소의 기공의 균일도는 증가하는 경향을 나타낸다. 탄소의 외 부로부터 세공을 도입하는 것에 더하여 탄소 내부에 내포된 공극도 존재하는데, 이런 공극은 통상 외부 표면에 연결된 열 린 세공(open pore)과 대조적으로, 외부 표면으로부터 닫힌 폐 공극(closed pore)으로 정의한다. 이런 폐공극은 탄소재에 의 한 흡착 및 촉매기능에 기여하지 못한다.

표면을 형성하는 “탄소”의 구조도 매우 중요하므로 세밀히 파악할 필요가 있다. 활성탄의 기능은 부분가스화 즉 활성화 에 의해 제공된 기공에 기인한 고비표면적, 외부에 드러난 탄
소의 표면 구조, 그리고 더불어 도입된 함산소 기능기에 의해 발현된다. 대부분의 활성화 공정은 탄소의 표면을 산화하는 것 으로, 산화제의 탄소표면에의 화학 흡착 과정(표면 함산소기 능기의 생성)과 분해 탈착 과정(연소)으로 이루어 진다. 화학 흡착 과정에서 남은 것이 표면 산소기능기에 해당한다. 즉, 탄 소의 표면은 물리적 구조가 어떠한가와 더불어 화학적으로 어 떤 특성이 있는가를 파악해야 한다. Fig. 1에서 보여주는 표면 구조의 인자는 다음과 같이 정리할 수 있다.

(1) 공간에 노출된 탄소면이 탄소육각망면의 기저면(basal plane), 에지면(edge surface)의 어느 쪽인가와 에지면일 경우, arm-chair형 에지인지, zigzag형 에지인지에 따라서 탄소의 표 면화학 반응이 좌우된다.

(2) 표면 탄소원자의 혼성궤도는 $\mathrm{SP}^{2}$ 만으로 구성되었다고 단 언할 수 없고, $\mathrm{SP}, \mathrm{SP}^{3}$ 도 존재할 가능성이 있다. $\mathrm{SP}^{2}, \mathrm{SP}^{3}$ 결합 에는 수소 및 산소 등으로부터 생성되는 치환 가능한 기능기 가 부착될 수 있다. 또한, 치환기를 가지지 않는 프리라디칼, 바이라디칼, 벤진 등도 존재할 수 있고, 이런 표면 분자종은 치환기의 탈착 후 탄소면이 축합하기 전에 나타나거나 주변 환경에 따라 안정화되어 남는다. 최근에 이런 기능기 및 표면 분자종의 중요성이 지적되고 있다.

(3) 치환기의 종류는 함산소기능기를 중심으로 파악할 수 있 
고, 종류와 더불어 함유량도 매우 중요하며, 가스화 및 후처리 등에 의해 제어가 가능하다.

(4) 탄소재를 구성하는 탄소육각망면의 골격 내에 질소, 황, 산소 등의 헤테로원소 등을 포함시키는 것도 가능하다. 탄소 원료의 선택 및 부활법, 그리고 탄화 후 도핑 등의 반응에 의 해 도입될 수 있다.

(5) 2 차원 그림으로서는 표현이 불가능하지만, 탄소육각망면 의 크기 $\left(\mathrm{L}_{\mathrm{a}}\right)$ 및 적층성 $\left(\mathrm{d}_{002}, \mathrm{~L}_{\mathrm{c}}\right)$, 즉 흑연화도 또는 결정성도 표면의 전자특성 및 반응성 측면에서 상당히 큰 영향을 미친다.

일반적으로 활성탄은 활성화가 용이한 등방성계의 난흑연화 성 탄소전구체를 불융화 하거나 낮은 탄화상태에서 부분 가스 화한 후, 탄화 공정 등을 거쳐 제조하므로, 구조 파괴가 심각 하여 생성된 활성탄의 “흑연”으로서의 구조는 종래에는 고려 하지 않았다. 그러나, 이방성계의 전구체를 이용하여 제조한 활성탄, 촉매를 이용한 가스화 및 다공성 탄소나노섬유 등 이 흑연화성 탄소로부터 유도한 흑연화도가 어느 정도 높은 활성 탄소도 제조 가능하다. 대용량 커패시터 등 용도에 따라서는 고기능이 발현되므로 최근에는 다공성 활성탄의 흑연화도에 대한 중요성이 인식되기 시작되고 있다 $[50,51]$.

\section{5. 탄소 표면의 촉매기능}

\section{1. 활성탄 및 활성탄소섬유의 $\mathrm{DeSO}_{x}$ 및 $\mathrm{DeNO} O_{x}$}

대기 혹은 배연 중에 존재하는 $\mathrm{SO}_{2}$ 가 활성탄에 흡착, 산화, 수화하여 황산으로 포착 제거되는 원리는 이전부터 잘 알려져 있으며, 생성된 황산을 회수하여 활성탄의 포착능을 재생하는 것이 실제 공정에서는 필수적이다[52-54].

$\mathrm{BF}$ 사(독일, 현 $\mathrm{DMT}$ 사)는, 값싼 고강도 활성코크스를 제조하 여, $\mathrm{SO}_{2}$ 를 포착하여 $\mathrm{H}_{2} \mathrm{SO}_{4}$ 화하고, 농축 $\mathrm{SO}_{2}$ 로서 회수하는 프 로세스를 제안하였다 $[55,56]$. 사용되는 활성코크스는 100 $150^{\circ} \mathrm{C}$ 에서의 $\mathrm{SO}_{2}$ 의 포착과 $400 \sim 700^{\circ} \mathrm{C}$ 에서의 $\mathrm{SO}_{2}$ 의 회수의 2단계 공정을 거친다. $\mathrm{SO}_{2}$ 의 회수에 있어서는 $\mathrm{SO}_{3}$ 의 환원과 정에서 탄소가 일부 소모된다.

필자 등은, $\mathrm{PAN}$ (polyacrylonitrile)계 $\mathrm{ACF}$ (activated carbon fiber)가 $\mathrm{SO}_{2}$ 의 포착 제거 활성이 높음을 보고하였으나[57], 상 기의 제거원리에 의해 고가의 $\mathrm{PAN}$ 계 $\mathrm{ACF}$ 가 소모되므로 공 업화까지의 진행을 유보하였다. 그 후, $\mathrm{ACF}$ 의 소모를 방지하 기 위하여, 소량의 수증기를 $\mathrm{ACF}$ 상에 응축시키고, $\mathrm{SO}_{2}$ 를 $\mathrm{H}_{2} \mathrm{SO}_{4}$ 으로 용출시켜 $\mathrm{ACF}$ 의 소모를 극소화하면서 포착능을 재생시키는 프로세스를 고안함으로써 본 공정의 공업화에 성 공하였다[52-54]. Fig. 8에 활성탄소섬유의 표면을 이용한 연 속탈황공정의 원리를 나타내었다. $\mathrm{ACF}$ 외의 활성탄을 사용하 여도 이론적으로 가능하지만, 활성탄은 활성탄소섬유에 비하 여 세공구조가 복잡하여 물의 응축을 비롯한 $\mathrm{H}_{2} \mathrm{SO}_{4}$ 의 용출과 관련된 활성점의 재생 또한 복잡한 과정을 거치게 되므로, 활 성점의 재생율이 저하되고 흡착이 원활히 진행되지 않는다. 더

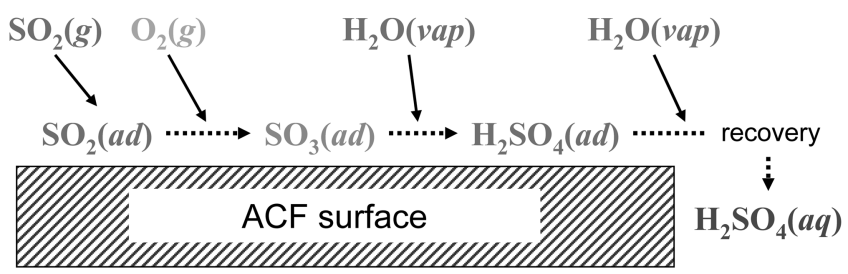

Fig. 8. Continuous $\mathrm{DeSO}_{\mathrm{x}}$ process concept using adsorption oxidation of $\mathrm{SO}_{2}$ on activated carbon fibers with its recovery as the form of sulfuric acid (cooperative research of Kyushu University, Mitsubishi Heavy Industry, and Osaka Gas).

욱이, 활성탄은 흡착 활성점의 재생을 위해 다량의 물을 필요 로 하므로 실용적이지 않다. 즉, 세공의 경로가 $\mathrm{ACF}$ 에 비해 길기 때문에, 물에 흡착된 $\mathrm{H}_{2} \mathrm{SO}_{4}$ 를 효과적으로 용출하면서, 재생을 위해 물을 세공에 침투시키는 것이 곤란하므로, 생성 된 $\mathrm{H}_{2} \mathrm{SO}_{4}$ 의 용출이 늦고, 재생을 위해 물을 다량 소모하는 악 순환이 계속되는 것이다.

흥미롭게도 피치계 고비표면적 $\mathrm{ACF}$ 를 $1100^{\circ} \mathrm{C}$ 까지 소성하 면, $\mathrm{SO}_{2}$ 등에 대한 탈황 성능이 급격히 증가하는 현상을 발견 하였다[58]. 적절한 $\mathrm{ACF}$ 의 선택 및 열처리 조건의 선정에 의 해 $\mathrm{SO}_{2}$ 의 흡착량, $\mathrm{SO}_{2}$ 의 산화 활성 및 $\mathrm{H}_{2} \mathrm{SO}_{4}$ 의 용출능이 현저히 증가한다. 상기의 열처리 온도에서 표면의 함산소기는 대부분 제거되고, $\mathrm{SO}_{2}$ 의 흡착용량이 분해생성되는 $\mathrm{CO} / \mathrm{CO}_{2}$ 로 측정할 수 있는 함산소기 중에 특정한 기능기의 양과 상관성 을 보임이 확인되어 있기 때문에, 함산소기능기가 분해된 지점 이 $\mathrm{SO}_{2}$ 에 대한 흡착 및 촉매반응 활성점으로 작용한다고 볼 수 있다. $\mathrm{SO}_{2}$ 의 흡착량은 $\mathrm{O}_{2}, \mathrm{H}_{2} \mathrm{O}$ 의 공존에 의해 증가하므로, 단 지 $\mathrm{SO}_{2}$ 의 흡착만이 아닌, 흡착 후 수화하여 $\mathrm{H}_{2} \mathrm{SO}_{4}$ 로서 용출 되는 용량과도 관계가 있다.

상술한탈황 공정(독일의 $\mathrm{BF}$ 사)에서 이용한 동일한 활성코크 스를 사용하여 $100 \sim 150^{\circ} \mathrm{C}$ 에서 $\mathrm{NO}_{\mathrm{x}}$ 의 암모니아 환원을 시도 한 결과, 탈황에 상당하는 정도로 탈질 반응 활성이 향상됨을 확인하였다[59]. 이때, 활성코크스를 탈황과 탈질 공정에 순차 적으로 반복하여 사용하면, 탈질에 대한 활성이 현저히 증가 하는 것을 발견하다. 그러한 활성의 향상은 표면의 함산소기 및 함질소기의 증가와 상관성이 있음을 확인하였다.

이와 같은 이유로 $\mathrm{PAN}$ 계 $\mathrm{ACF}$, 특히 황산으로 재부활시킨 $\mathrm{ACF}$ 를 사용하는 경우, 탈질 성능이 현저하게 증가함을 발견 하였다[60]. 이런 고활성 PAN계 ACF는 실온에서 암모니아를 포착하여 포착된 암모니아가 NO와 반응할 수 있기 때문에, 실 온 암모니아환원 탈질을 시도할 수 있다. $100 \sim 150^{\circ} \mathrm{C}$ 에서의 탈질에는 암모니아의 흡착량과 활성과의 사이에 상관성이 나 타나지만, 실온 탈질 활성은 오히려 $\mathrm{NO}$ 의 산화적 흡착 간의 상관성이 크기 때문에, 흡착된 $\mathrm{NO}_{2}$ 와 $\mathrm{NH}_{3}$ 의 반응이 중요함을 시사한다. Fig. 9에 ACF표면상의 탈질반응 원리를 나타내었다.

고활성에 의해 실온 반응이 가능한 반면, 이 경우는 습도에 의한 활성저하가 큰 편이고 특히 습도가 $60 \%$ 를 넘으면 활성이 현저히 저하하는 문제점이 있다[61]. ACF를 열처리하면 함산 소기가 분해 제거되어 소수성(hydrophobicity)이 증가하므로, 열 


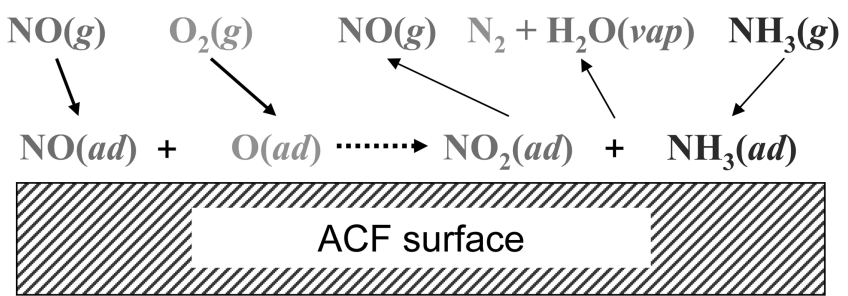

Fig. 9. DeNO $\mathrm{x}_{\mathrm{x}}$ process concept using the surface reaction of $\mathrm{NO}$ and ammonia on activated carbon fibers, which is effective in the removal of low concentration $\mathrm{NO}$ at a low temperature (cooperative research of Kyushu University and Mitsui Mining).

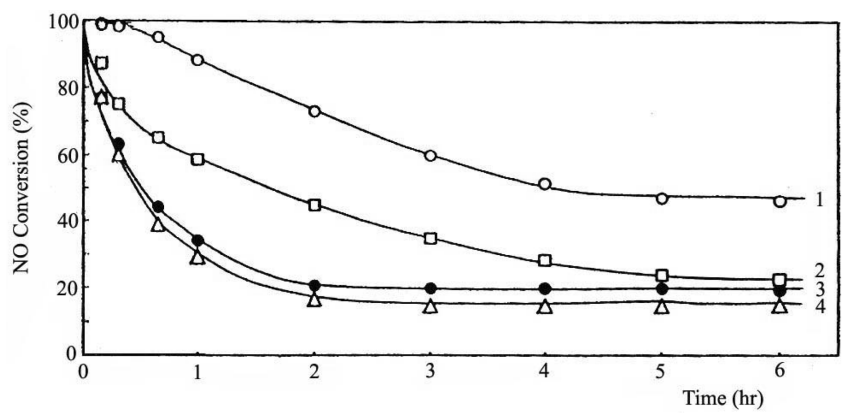

Fig. 10. NO-ammonia reaction over pitch-based activated carbon fibers with heat treatment at $1100^{\circ} \mathrm{C}\left(\mathrm{NO}: \mathrm{NH}_{3}=1: 1\right.$ (NO 200 $\mathrm{ppm}), \mathrm{O}_{2}=4 \%, \mathrm{~N}_{2}=$ balance, $\mathrm{W}=5 \times 10-3 \mathrm{~g} \cdot \mathrm{min} \cdot \mathrm{ml}^{-1}$, Temperature $=25^{\circ} \mathrm{C}$, Wet $(\mathrm{RH}=80 \%), 1:$ OG20A-H1100, $2:$ OG15AH1100, 3 : OG8A-H1100, 4 : OG7A-H1100) [63].

처리에 의해 내습도 특성을 향상시키면 Fig. 10에 나타낸 바 와 같이 활성을 크게 향상시킬 수 있다. 고비표면적 피치계 활 성탄소섬유를 열처리 후 이용하면 더욱 활성이 향상된다[62, 63].

이와 같이, 저습 실온 상태의 $\mathrm{ACF}$ 표면에서 $\mathrm{NO}^{-\mathrm{NH}_{3}}$ 반응이 가능하여, 실온탈질 공정을 구축할 수 있다. 단, 배연 탈질에 대 해서는 특히 고습도 하에서의 활성을 현재의 2 배 정도 향상시 키는 것이 바람직하다. 탈황 공정과의 조합이 필수이므로 양자 의 조합을 최적화하는 설계가 요구된다. 한편, 저농도의 $\mathrm{NO}$ 에 대해서는, $\mathrm{NO}$ 의 산화적 포착 혹은 흡착 $\mathrm{NH}_{3}$ 에 의한 환원에서 도 설계조건에 따라서 실용적인 탈질 설계가 가능하다.

배연 $\mathrm{NO}_{\mathrm{x}}$ 물질의 제거 및 무해화를 위해서는 암모니아 또
는 에탄올 등의 환원제가 이용된다. $\mathrm{NO}_{\mathrm{x}}$ 무해화 제거를 위해 서는 암모니아 등의 독성 가스를 이용할 수 없다. 필자들은 암 모니아 대신에 요소를 침투시킨 피치계 활성탄소섬유를 이용 하여, 대기 조건에서 $\mathrm{NO}_{2}$ 의 장시간 완전 무해화에 성공하였 다. 다음 식 (1)에 나타낸 것과 같이, $\mathrm{NO}$ 는 우선 공기 중의 산 소와 반응하여 $\mathrm{NO}_{2}$ 가 되고, 이어서 요소와 반응하여 질소와 $\mathrm{CO}_{2}$ 가 되는 무해화 과정을 따른다[64].

$$
\mathrm{NO}_{2}+\mathrm{NO}+\left(\mathrm{NH}_{2}\right)_{2} \mathrm{CO} \rightarrow 2 \mathrm{~N}_{2}+\mathrm{CO}_{2}+\mathrm{H}_{2} \mathrm{O}
$$

\section{2. 활성탄소섬유의 기상성장 $C N F$ 복합화에 의한 고활성화}

탄소나노섬유(carbon nanofiber, $\mathrm{CNF}$ )는 표면이 특정한 면 으로 균일하게 이루어져 있어서 활성탄에 비하여 극히 고활성 을 보일 가능성이 있다. 하지만, $\mathrm{CNF}$ 를 촉매로서 사용하는 경 우, 직경이 나노미터 크기로 매우 미세하여, 탈황 또는 탈질 반 응 중의 물이 $\mathrm{CNF}$ 표면에서 대량으로 응축되고, 통기성을 저 해하는 등의 탈황 효율의 저하 요인이 다수 발생한다. 또한, 통 기형 반응의 경우, 고정화가 곤란하고 취급이 어려우며, 압력 강하 등의 문제를 초래할 수 있다. 필자들은 이러한 취급상의 문제를 해결함과 동시에 흡착전환반응의 고성능화를 모색하는 방법으로서 $\mathrm{ACF}$ 표면상에 $\mathrm{CNF}$ 를 성장시킨 CNF-ACF 복합 체의 응용을 시도한 사례를 소개한다.

Fig. 11에는 PAN계 활성탄소섬유(FE300, TOHO TENAX) 와 피치계 활성탄소섬유(OG15A, Osaka Gas) 상에 CNF를 성 장시킨 $\mathrm{CNF}-\mathrm{ACF}$ 복합체의 $\mathrm{SEM}$ 사진을 나타내었다. $\mathrm{CNF}$ 코 팅의 촉매에는, 철-니켈 촉매를 사용하여, 에칠렌/수소 기류로 $500 \sim 600^{\circ} \mathrm{C}$ 에서 합성시간을 변화시키며 $\mathrm{CNF}$ 의 석출량을 제 어할 수 있었다[65]. 합성된 CNF는 헤링본(herringbone) 구조 를 하고 있다.

하지만, $\mathrm{CNF}$ 코팅을 위한 촉매를 $\mathrm{ACF}$ 에 담지하는 공정에서 이미 $\mathrm{ACF}$ 의 비표면적은 급격히 감소하고, $\mathrm{CNF}$ 를 성장시킨 후에도 복합체의 비표면적은 향상되지않고 $100 \sim 150 \mathrm{~m}^{2} / \mathrm{g}$ 수 준에 머물렀다. 이는 $\mathrm{CNF}$ 의 합성촉매가 활성탄소섬유의 마이 크로기공에 선택적으로 흡착됨을 시사한다. 비표면적의 감소 는 표면활성의 저하로 이어지고, $\mathrm{ACF}$ 는 값비싼 담지체 역할 이상의 의미를 상실한다.

이러한 문제를 개선하기 위하여 CNF 합성촉매를 담지한 후

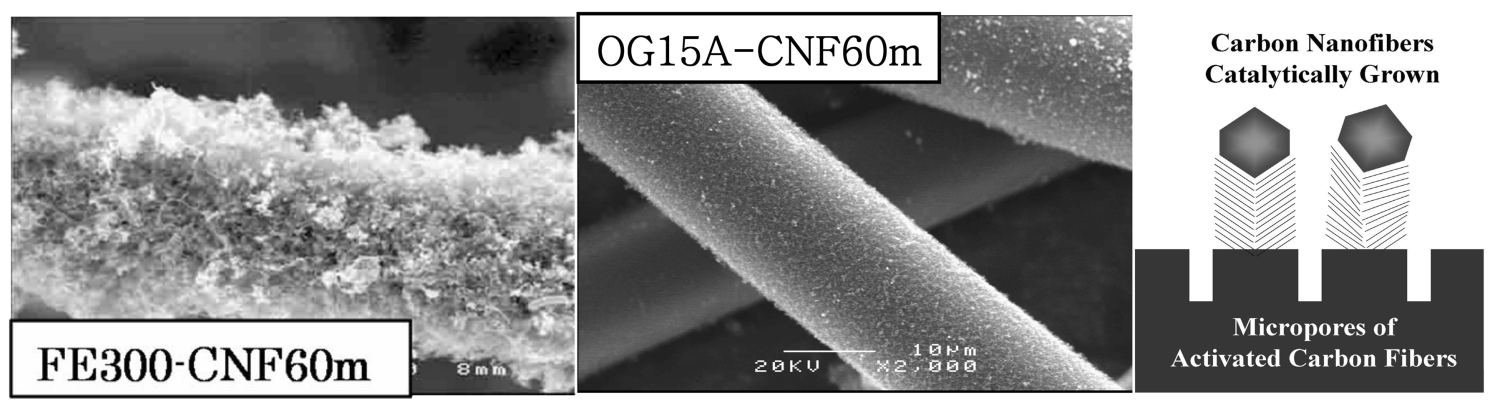

Fig. 11. SEM images of CNF-deposited PAN-based ACF (FE300; TOHO TENAX) and pitch-based ACF(OG15A; Osaka Gas), and a conceptual cartoon of CNF-ACF composites [65]. 


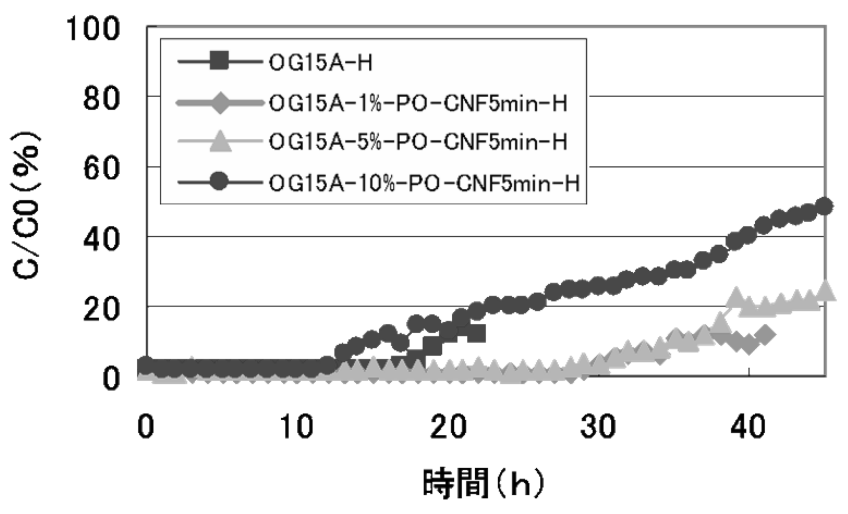

Fig. 12. DeSOx activity of pitch-based ACFs and the CNF-ACF composites: the activity dependency on the amount of CNF deposition [66].

에 부분산화시키는 방법을 도입하여, 복합체의 비표면적을 대 폭 개선 할 수 있었고, Table 1에 나타낸 바와 같이 CNF 석출 량의 조절로 $\mathrm{CNF}-\mathrm{ACF}$ 복합체의 비표면적을 효과적으로 제어 하는 단계에 이르렀다. 이러한 결과로 당초에 특성이 다른 두 가지 표면을 동시에 이용하고자 한 목표를 달성할 수 있었고, 상승 작용에 의한 추가적 성능 향상에 대한 기대도 할 수 있 게 되었다.

Fig. 12에 기존의 ACF 및 CNF-ACF 복합체의 탈황 성능을 비교하여 나타냈다 [66]. 앞 절에서 언급한 바와 같이, 최대 활 성을 나타낸 $1100^{\circ} \mathrm{C}$ 열처리 $\mathrm{ACF}$ 를 이용한 경우, 약 17 시간의 완전탈황시간 (breakthrough time)을 달성한 후, 탈황률이 점 진적으로 감소한다. $\mathrm{CNF}-\mathrm{ACF}$ 복합체의 경우, $\mathrm{CNF}$ 석출양에 따라서 탈황 성능이 크게 좌우됨을 알 수 있었다. $\mathrm{ACF}$ 의 기 공과 $\mathrm{CNF}$ 의 표면이 효과적으로 작용할 경우, 완전탈황시간 28 시간 이상의 고활성 촉매 기능이 발휘됨을 관찰할 수 있었다.

\section{3. 보조촉매와의 조합에 의한 배연탈황, 탈질 활성의 향상}

고비표면적을 지닌 입상 활성탄 및 활성탄소섬유(ACF)에 활 성금속을 고분산시키는 것에 의해, 저온에서 $\mathrm{NOx}$ 를 선택적으 로 접촉 환원할 수 있는 촉매도 개발되어 있다. 필자들은 입 상 활성탄, $\mathrm{ACF}$, 알루미나 분말 등에 보조촉매로서 철, 코발 트, 망간 등의 산화물을 $0.1 \sim 5 \%$ 미량 담지함으로써 $\mathrm{NO}$ 환원 반응에 대한 활성을 대폭 향상시키는 촉매를 개발하는 중이다.

\section{6. 탄소표면의 촉매담지체기능}

\section{1. 탄소담지체촉매의 수소화 활성}

탄소담지촉매를 이용한 다환방향족 탄화수소류 (피렌, 플루 오란덴, 아크리딘, 카바졸 등)의 저온수소화에서, 다환방향족 탄화수소의 수소화 선택성이 담지체, 귀금속종, 혹은 기질의
Table 1. Dependency of specific surface area of CNF-ACF composites on the CNF growth time

\begin{tabular}{ccccc}
\hline \multicolumn{2}{c}{ CNF growth time $(\mathrm{min})$} & 0 & 20 & 60 \\
\hline $\begin{array}{c}\text { BET surface area } \\
\left(\mathrm{m}^{2} / \mathrm{g}\right)\end{array}$ & FE300 & 700 & 600 & 100 \\
\cline { 2 - 5 } & OG15A & 1530 & 600 & 400 \\
\hline
\end{tabular}

Table 2. Activity of KB-supported catalysts in hydrogenation of 1-methyl naphthalene [68]

\begin{tabular}{ccc}
\hline \multirow{2}{*}{ Catalysts } & \multicolumn{2}{c}{ Conversion (hydrogenation) $(\%)$} \\
\cline { 2 - 3 } & $350^{\circ} \mathrm{C}$ & $400^{\circ} \mathrm{C}$ \\
\hline $\mathrm{Fe}(15) / \mathrm{KB}$ & $<1$ & 2 \\
$\mathrm{Ni}(2) \mathrm{Fe}(10) / \mathrm{KB}$ & 2 & 4 \\
$\mathrm{Mo}(2) \mathrm{Fe}(10) / \mathrm{KB}$ & 1 & 7 \\
$\mathrm{Ni}(2) \mathrm{Mo}(10) / \mathrm{KB}$ & 34 & 50 \\
\hline
\end{tabular}

골격구조, 전자밀도, 결합차수 등에 의해 크게 다른 것이 밝혀 졌다[67]. Table 2에는 $350^{\circ} \mathrm{C}$ 및 $400^{\circ} \mathrm{C}$ 에 있어서 $\mathrm{KB}$ (Ketjen black $\mathrm{EC}$, 도전성 카본블랙의 일종) 담지 $\mathrm{Fe}$ 계 및 $\mathrm{NiMo}$ 촉매 의 1-메칠 나프탈렌에 대한 수소화 전환율을 정리하였다[68]. $350^{\circ} \mathrm{C}$ 에서는 $\mathrm{NiMo} / \mathrm{KB}$ 촉매가, $34 \%$ 의 비교적 높은 수소화 전 환율을 나타내었으나, 기타 다른 2종의 철계 촉매에서는, $\mathrm{Ni}$ 혹은 $\mathrm{Mo}$ 을 $2 \mathrm{wt} \%$ 첨가하여도 1-2\%의 매우 낮은 수소화전환 율에 지나지 않는다. 방향환 수소화 활성에 대한 $\mathrm{Ni} / \mathrm{Mo}$ 간의 현저한 상승적 효과가 확인되었다. 반응온도를 $400^{\circ} \mathrm{C}$ 에 상승 하면, 어떤 촉매에 대해서도 수소화 전환율이 높아지지만, 철 계 촉매에서는 전환율은 $10 \%$ 이하의 저 수준에 머문다. 이에 비해 $\mathrm{NiMo} / \mathrm{KB}$ 촉매는 $50 \%$ 의 높은 수소화 활성을 나타낸다.

Table 3에는 각종 탄소 담지체에 담지한 $\mathrm{NiMo}$ 촉매의 1-메 칠 나프탈렌에 대한 수소화 전환율을 정리하였다[67]. 350 혹 은 $425 \mathrm{~m}^{2} / \mathrm{g}$ 의 표면적을 지닌 Active Coke-A 및 B에 담지한 $\mathrm{NiMo}$ 촉매의 수소화 전환율은 담지법을 바꾸거나 입경을 바 꾸어도 거의 $10 \%$ 수준으로 향상 하지 않았다. 플러렌숱 (fullerene soot)의 TI (toluene insoluble)을 담지체로서 조제한 촉매의 경우가 수용성의 금속염으로 제조한 촉매보다 높은 수 소화 전환율을 나타내었다. $1000 \mathrm{~m}^{2} / \mathrm{g}$ 이상의 고비표면적을 지 닌 석탄계 활성탄 내지는 카본블랙계의 KB-EC, BP2000에 담 지한 $\mathrm{NiMo}$ 촉매는 담지법 및 입경에 관계없이 $40 \sim 70 \%$ 의 높 은 수소화 전환율을 나타내었다. 또한 입경이 큰 것에도 상관 없이 수소화 전환율이 거의 감소하지 않는 것으로부터, 고정 상형 담지 촉매에의 응용 가능성도 기대된다.

\section{2. 촉매 담지 $\mathrm{Mo}$ 계 촉매의 수소화 탈황특성}

Table 4에 활성탄 담지 CoMo촉매의 4,6-DMDBT (4,6dimethyl dibenzothiophene)탈황반응에 대한 활성을 알루미나 담지 $\mathrm{CoMo}$ 촉매와 비교하여 나타내었다 $[69,70]$. DBT의 탈황 반응에서는 어떤 $\mathrm{CoMo} / \mathrm{C}$ 촉매도 시판 $\mathrm{CoMo} / \mathrm{A} 12 \mathrm{O} 3$ 담지 촉 
Table 3. Activity of carbon-supported NiMo catalysts in hydrogenation of 1-methyl naphthalene [67]

\begin{tabular}{lccc}
\hline \multicolumn{1}{c}{ Supports } & Specific Surface Area $\left(\mathrm{m}^{2} / \mathrm{g}\right)$ & Particle Size & Conversion $(\%)$ \\
\hline Activated coke-A & 350 & $<200 \mathrm{mesh}$ & 7.7 \\
Activated coke-B & 425 & $<60$ mesh & 8.6 \\
Activated coke-B & 425 & $<60$ mesh & 6.7 \\
Activated coke-B & 425 & $<200$ mesh & 11.9 \\
Activated carbon & 1350 & $<200 \mathrm{mesh}$ & 43.1 \\
Activated carbon & 1350 & $<1 \sim 2 \mathrm{~mm}$ & 38.7 \\
Fullerenes-Toluene Insolubles & 343 & $30 \sim 50 \mathrm{~nm}$ & 8.6 \\
MAXSORBII & 2972 & $<200 \mathrm{mesh}$ & 55.2 \\
Black Pearl 2000 & 1450 & $20 \mathrm{~nm}$ & 65.2 \\
BP/PyCVD & - & $20 \mathrm{~nm}$ & 47.4 \\
KB-EC & 1270 & $30 \mathrm{~nm}$ & 68.3 \\
KB/PyCVD & - & $30 \mathrm{~nm}$ & 55.3
\end{tabular}

*1-methylnaphthalene $1.0 \mathrm{~g}$ in decalin $9.0 \mathrm{~g}$ with $0.01 \mathrm{~g}$ of catalyst at $360^{\circ} \mathrm{C}, 10 \mathrm{MPa} \mathrm{H} 2,1 \mathrm{~h}$

*PyCVD: Pyridine CVD treatment at $725^{\circ} \mathrm{C}$

Table 4. Activity of activated carbon-supported CoMo catalysts in hydrodesulfurizaion of 4,6-DMDBT in comparison with an alumina-supported CoMo catalyst [69]

\begin{tabular}{|c|c|c|c|c|c|c|c|c|c|}
\hline \multirow{2}{*}{$\begin{array}{l}\text { Catalyst } \\
\text { MC-I-A }^{1)}\end{array}$} & \multirow{2}{*}{$\frac{k_{D B T}{ }^{10^{4}} \sec ^{-1} g_{c a t}{ }^{-1}}{104.7}$} & \multirow{2}{*}{$\frac{k_{D B T}{ }^{10^{4}} \sec ^{-1} g c a t^{-1}}{18.6}$} & \multicolumn{4}{|c|}{$\begin{array}{l}\text { Product selectivities of DBT at the same } \\
\text { conversion level }\end{array}$} & \multicolumn{3}{|c|}{$\begin{array}{l}\text { Product selectivities of } \\
\text { 4,6-DMDBT at the same } \\
\text { conversion level }\end{array}$} \\
\hline & & & 0 & 10.4 & 87.6 & 2.0 & 43.1 & 53.5 & 3.3 \\
\hline MC-II-A ${ }^{2)}$ & 214.5 & 36.0 & 0 & 14.7 & 85.1 & 0.2 & 37.8 & 59.5 & 2.7 \\
\hline MC-I-B ${ }^{3)}$ & 124.1 & 12.2 & 0 & 13.5 & 86.1 & 0.4 & 34.8 & 57.7 & 7.4 \\
\hline MC-II-B ${ }^{4)}$ & 193.1 & 17.5 & 0 & 21.3 & 78.4 & 0.3 & 38.1 & 58.2 & 3.6 \\
\hline $\mathrm{Co}-\mathrm{Mo} / \mathrm{Al}_{2} \mathrm{O}_{3}$ & 60.0 & 19.0 & 0.8 & 15.0 & 83.7 & 0.5 & 50.3 & 47.1 & 2.6 \\
\hline
\end{tabular}

1) MC-I-A: Active Carbon A(907 m2/g) - successive impregnation of Mo and Co followed by sulfidation

2) MC-II-A: Active Carbon A(907 m2/g) - successive impregnation of Mo and Co with sulfidation in between

3) MC-I-B: Active Carbon B(3213 m2/g) - successive impregnation of Mo and Co followed by sulfidation

4) MC-II-B: Active Carbon B(3213 m2/g) - successive impregnation of Mo and Co with sulfidation in between

매에 비해 높은 활성을 나타내었지만, 4,6-DMDBT의 탈황에 대하여서는 $\mathrm{Mo}, \mathrm{Co}$ 를 각각 축차 함침, 황화하여 제조한 $\mathrm{CoMo-}$ II-A촉매가 특히 고활성을 나타내었다. 또한, 4,6-DMDBT의 탈황에 대해서는 비표면적은 작지만 평균 기공경이 큰 (약 $25 \AA$ )활성탄 $\mathrm{A}$ 에 담지한 촉매의 경우가 고활성이었다. 기질의 분자 사이즈에 의해 탄소담지체의 세공경을 최적화할 필요가 있는 것을 시사하고 있다.

\section{3. $\mathrm{KB}$ 담지 $\mathrm{Fe}$ 계 및 $\mathrm{Mo}$ 계 촉매의 석탄 액화 특성}

3종의 철염(푸말산철, 철 아세트아세테이트-황산철)울 각각 담지한 $\mathrm{Fe}$ 계/KB 촉매를 이용한 다니트할름 탄의 액화반응에
대한 철염종의 영향을 조사한 결과, $\mathrm{Fe}(15) / \mathrm{KB}(\mathrm{Fe}$ 후말산철 $)$ 은 합성바이오라이트와 거의 같은 오일 수율 $(58.3 \%)$ 을 나타내었 다[70]. 그러나 $\mathrm{Fe}(15) / \mathrm{KB}$ ] 촉매의 금속 $\mathrm{Fe}$ 를 합성 바이오라 이트와 비교하면, 약 $1 / 12$ 이므로, 고분산 및 고활성이 달성 가 능하다고 말 할 수 있다. 더욱 철염의 종류의 차이에 의해 액 화활성이 다른 것으로부터 철염, 촉매황화법 등의 탐색에 의 한 활성의 향상이 기대된다.

Fig. 13에는 타니트할름탄의 액화 반응에 대한 각종 $\mathrm{KB}$ 담 지 촉매의 활성을 비교하여 나타내었다. $\mathrm{NiFe}$ 계 촉매에 있어 서, $\mathrm{Ni}$ 의 함량을 2, 5, $10 \mathrm{wt} \%$ 로 증대하면, 오일 수율이 서서 히 상승하여 $\mathrm{Ni}(10) \mathrm{Fe}(10) / \mathrm{KB}$ 촉매에서 약 $70 \%$ 에 달하였다. 이 것에 대하여, $\mathrm{Mo}(2) \mathrm{Fe}(10) / \mathrm{KB}$ 촉매에서는 $2 \mathrm{wt} \%$ 의 적은 $\mathrm{Mo}$ 첨 


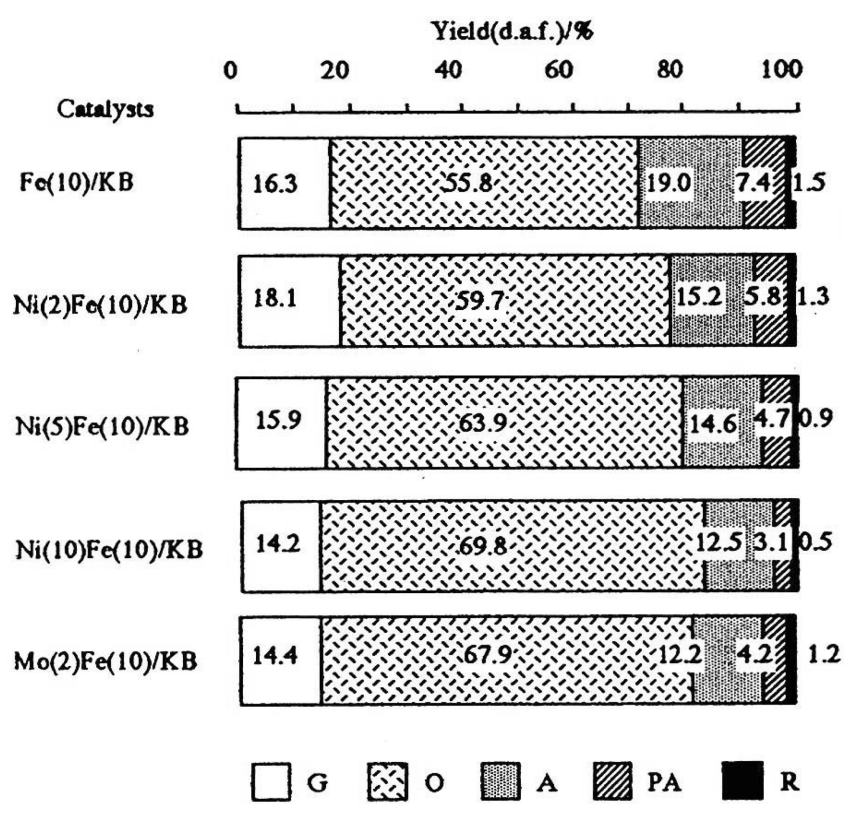

Fig. 13. Effect of $\mathrm{Ni}$ or Mo addition to the $\mathrm{Fe}(10) / \mathrm{KB}$ catalyst on the liquefaction of Tanitoharum coal [71].

가에 의해 $\mathrm{Ni}(2) \mathrm{Mo}(10) / \mathrm{KB}$ 에 필적하는 약 $70 \%$ 의 오일 수율 을 나타내어 $\mathrm{Fe} / \mathrm{KB}$ 촉매에 대한 $\mathrm{Mo}$ 의 첨가효과가 보다 높은 것을 나타내었다.

이상의 결과로부터, 탄소미립자 담지 철계 촉매는, 회수기능 을 지니고 비교적 저가이며, 종래의 철계 촉매보다 고활성임 보였다. 또한, 철에 대하여 $\mathrm{Ni}$ 혹은 $\mathrm{Mo}$ 를 소량 첨가시키는 것 에 의해 $\mathrm{NiMo}$ 촉매에 필적하는 액화활성을 얻을 수 있었다.

\section{4. 고활성 수소화반응을 위한 탄소나노섬유 담지 촉매}

최근, 함산소기능기가 거의 없고 비교적 균질한 표면 구조 를 특징으로 하는 $\mathrm{CNF}$ 를 담지체로 이용하여, 방향족 유기물 의 수소화용 Ru-CNF 촉매에 대하여 검토한 사례가 있다[72, 73]. 튜브형 (tubular), 헤링본형, 플레이트릿형 (platelet)의 3가 지 구조의 $\mathrm{CNF}[74]$ 를 담지체로 적용하고, $\mathrm{CNF}$ 를 분산시킨 톨 루엔 현탁액에 루테니움 카르보닐 착체 $\left(\mathrm{Ru}_{3}(\mathrm{CO})_{12}\right)$ 를 첨가하
여 reflux 방법으로 촉매를 제조하였다. 이와 같은 촉매 합성 방법에 의하여, 탄소 표면 구조 및 특성에 관계없이 비교적 균 일하게 Ru 나노입자가 형성되었다(Fig. 14). 하지만, 수소화 반 응 결과, 튜브형은 활성이 낮고, 헤링본형에서는 재현성이 부 족한 반면, 플레이트릿형을 이용한 경우는 시판촉매(활성탄 담 지 $\mathrm{Ru}$ 촉매)를 훨씬 넘어서는 고활성을 보이는 등, 촉매 활성 에서 현저한 차이를 나타냈다.

방향족화합물의 핵수소화반응에 있어서 시판 활성탄 담지 촉매와 비교할 때, 플레이트릿형 $\mathrm{CNF}$ 담지 촉매는 활성에서 뿐 만 아니라, 촉매 재활용 및 반응 후 금속유출(metal leaching) 등에 있어서도 상당히 우수함을 알 수 있었다. 이러한 결과로 볼 때, 함산소기능기 및 미세 기공의 도움 없이도 플레이트릿 형 $\mathrm{CNF}$ 의 표면(대부분 에지로 구성)에의 촉매 입자 부착성이 상당히 우수함을 추측할 수 있었다.

$\mathrm{Ru}$ 플레이트릿형 $\mathrm{CNF}$ 의 또 다른 특징으로서, 단환 방향족 화합물의 경우(Table 5), 통상 반응성이 낮은 카르보닐기 및 질 소기능기를 가지고 있는 기질에 대해서도 Anigilici 촉매 $\left(\mathrm{Pd} / \mathrm{SiO}_{2}\right.$ 담지 $\mathrm{Rh}$ 촉매)와 유사하거나 더 우수한 활성을 나타냈다. 즉, 기능기 선택적 환원성에 우수하여, 예를 들면, 수소화 분해가 발생하기 쉬운 페닐에테르류 또는 커플링이 일어나기 쉬운 아 닐린 등의 반응에서 선택성 $100 \%$ 가까운 단일 생성물 반응 특성을 보였다. 또한, 광학적으로 순수한 반응물이 라세미화가 병행되지 않고 반응이 진행되는 특성을 보이기도 하였다. 이 와 같이, $\mathrm{Ru}$ 플레이트릿형 $\mathrm{CNF}$ 는 다양한 기능기를 가진 단환 방향족 화합물의 환수소화 반응에서 고활성, 고수율, 기능기선 택성 등의 우수한 특성을 나타냄을 알 수 있었다.

이러한 고활성 및 선택성이 $\mathrm{CNF}$ 의 어떤 특성에서 유래하였 는지 아직 정확히 규명할 수 없지만, 기존 탄소재료와 차별화 되는 고결정성의 균일한 표면구조의 탄소나노재료는 새로운 표 면 기능성 재료로서 신중히 검토해 볼 가치가 있음을 시사한다.

\section{7. 결 론}

이상 서술한 바와 같이, 탄소는 다양한 구조 및 형상, 우수한 성형성, 고비표면적과 더불어, 표면수식, 세공제어 등에 의한
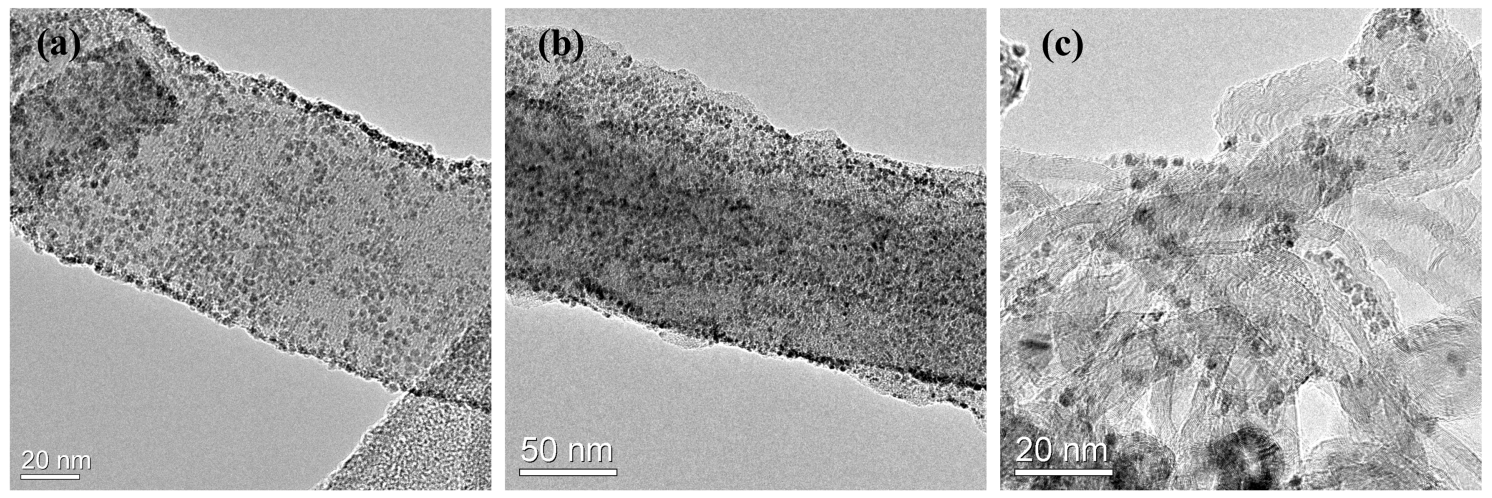

Fig. 14. TEM images of Ru catalysts supported on platelet CNF (a), herringbone CNF (b), and tubular CNF (c). 
Table 5. Hydrogenation activity of the Ru/platelet CNF catalyst [72]

\begin{tabular}{ccccc} 
Entry Substrate & $\begin{array}{c}\text { Time } \\
(\mathrm{h})\end{array}$ & Product & $\begin{array}{c}\text { Yield }^{1)} \\
(\%)\end{array}$ & $\begin{array}{c}\mathrm{TON}^{2)} \\
{[\mathrm{TOF}] \mathrm{b}}\end{array}$ \\
\hline & & $>99$ & $\begin{array}{c}35800 \\
{[14300]} \\
8300\end{array}$ \\
{$[1660]$}
\end{tabular}

*Conditions : $1 \mathrm{~mL}$ of substrate, $5 \mathrm{mg}$ of $\mathrm{Ru} / \mathrm{CNF}-\mathrm{P}(1.7 \mathrm{wt} \%$ $\mathrm{Ru})$ at $100^{\circ} \mathrm{C}$ under $30 \mathrm{~atm}$ of $\mathrm{H}_{2}$

${ }^{1)}$ Determined by capillary GLC analysis

${ }^{2} \mathrm{TON}=\mathrm{mol}($ substrate $) / \mathrm{mol}(\mathrm{Ru}) ; \mathrm{TOF}=\mathrm{TON} / \mathrm{h}$

3) $3 \mathrm{~mL}$ of toluene was used

${ }^{4)}$ Determined by $1 \mathrm{H}$ NMR analysis

${ }^{5)} 0.5 \mathrm{~mL}$ of substrate was used under $\mathrm{H}_{2}$ (20 atm)

${ }^{6}$ THF (2 mL) was used as a solvent.

다양한 표면 물리화학적 특성으로 인하여 우수한 흡착재료, 촉 매 및 촉매담지체로서 이용되고 있다. 본 소론에서는, 이러한 표면 기능성 탄소재료를 촉매 및 촉매담지체로 활용한 배연탈 황, 탈질, 가스분리, 방향족 수소화, 석유탈황, 탈질소 및 석탄 액화 등의 연구와 고효율화 과정에 대하여 최근의 연구를 필 자 등의 성과를 중심으로 소개하였다.

최근 연료전지에 대한 관심이 증폭되면서, 특히 고분자전해 질형 또는 직접메탄올형 연료전지와 같은 저온형 연료전지 연 구 개발에 있어서 전극재료 및 촉매담지체로서의 탄소재료에 대한 수많은 연구가 보고되어 왔다 $[75,76]$. 고활성 촉매 제조 를 위한 탄소재료의 합성 및 구조 제어가 주를 이루어 왔고, 연료전지의 실용화를 목전에 두고 있는 현재에는 활성의 증진 과 더불어 내산화성, 내부식성 등의 내구성을 함께 확보할 수 있는 탄소재료의 개발이 절실히 요구되고 있다. 한편, 희귀금 속 촉매를 대체하는 다양한 시도 중에 나노탄소의 표면 및 질
소 등으로 개질된 탄소 표면을 연료전지의 촉매[77, 78] 또는 유기 단위 반응 촉매로[79] 활용하고자 하는 노력도 진행되는 중이다. 아직 기본적인 연구 단계이지만, 탄소 표면구조의 정 밀한 설계 및 물리 화학적 데이터의 축적과 함께 성장할 수 있 는 잠재력을 가진 분야임에 틀림없다.

향후 더욱 엄격해질 것으로 예상되는 지역환경보전에 대한 요구에 대응하기 위해서는 이러한 표면 고기능성 탄소재료에 대한 연구 개발 및 고도 활용이 점차적으로 중요하게 부각될 것으로 보인다.

\section{참고문헌}

[1] Mochida, I. "Chemistry and Engineering of Carbon Materials (Japanese original title: 炭素材の化学と工学)”, Asakurashoten, Tokyo, 1990.

[2] Yamada, Y. “Application Technology of Carbon Materials (Japanese original title: カーボン材料応用技術)”, Nikkankougyo-shinbunsha, Tokyo, 1992.

[3] Marsh, H.; Rodriguez-Reinoso, F. "Activated Carbon", Elsevier, Oxford, 2000.

[4] Marsh, H.; Diaz-Estebanez, M. D. "Sciences of Carbon Materials", ed. H. Marsh and F. Rodriguez-Reinoso, Universidad de Alicante, Alicante, 2000, 353.

[5] Mochida, I.; Korai, Y.; Sakanishi, K. Shokkubai 1999, 248, 133.

[6] Radovic, L. R.; Rodriguez-Reinoso, F. "Chemistry and Physics of Carbon", Vol. 25, ed. P. A. Thrower, Marcel Dekker, New York, 1997, 243.

[7] Choi, S. U. S.; Zhang, Z. G; Keblinski, P. Nanofluids, "Encyclopedia of Nanoscience and Nanotechnology", Vol. $\mathrm{X}$, ed. H. S. Nalwa, American Scientific Publishers, Valencia (CA), 2003, 1.

[8] Maruyama, S. et al. "Handbook of micro and nano thermal fluids (Japanese original title: マイクロ・ナノ熱流体ハンドブ ック)", N.T.S, Tokyo, 2006, 231.

[9] Conway, B. E. "Electrochemical Supercapacitors: Scientific Fundamentals and Technological Applications", Kluwer Academic/Plenum Publishers, New York, 1999, 183.

[10] Nishino, A. Journal of Power Sources 1996, 60(2), 137.

[11] Ogumi, Z.; Inaba. M. Carbon Anodes, "Advances in Lithium-Ion Batteries", ed. W. A. Schalkwijk and B. Scrosati, Kluwer Academic/Plenum Publishers, New York, 2002, 79.

[12] Chen, J.; Hamon, M. A.; Hu, H.; Chen, Y.; Rao, A. M.; Eklund, P. C.; Haddon, R. C. Science 1998, 282 (5386), 95.

[13] Haddon, R. C. Nature 1995, 378 (6553), 249.

[14] Yoon, S. H.; Korai, Y.; Mochida I. "Sciences of Carbon Materials", ed. H. Marsh, F. Rodriguez-Reinoso, Universidad de Alicante, Alicante, 2000, 287. 
[15] Joo, S. H.; Choi, S. J.; Oh, I.; Kwak, J.; Liu, Z.; Terasaki, O.; Ryoo, R. Nature 2001, 412 (6843), 169.

[16] Lee, J.; Kim, J.; Hyeon, T. Advanced Materials 2006, 18 (16), 2073.

[17] De Jong, K. P.; Geus, J. W. Catalysis Reviews-Science and Engineering 2000, 42 (4), 481.

[18] Rodriguez, N. M. A. J. Materials Research 1993, 8 (12), 3233.

[19] Iijima, S. Nature 1991, 354 (6348), 56.

[20] Iijima, S.; Yudasaka, M.; Yamada, R.; Bandow, S.; Suenaga, K.; Kokai, F.; Takahashi, K. Chemical Physics Letters 1999, 309 (3-4), 165.

[21] Kroto, H. W.; Heath, J. R.; O'Brien, S. C.; Curl, R. F.; Smalley, R. E. Nature 1985, 318 (6042), 162.

[22] Diederich, F.; Ettl, R.; Rubin, Y.; Whetten, R. L.; Beck, R.; Alvarez, M.; Anz, S. et al. Science 1991, 252 (5005), 548.

[23] Ugarte, D. Nature 1992, 359(6397), 707.

[24] Nienow, A. M.; Roberts, J. T. Annual Review of Physical Chemistry 2006, 57105.

[25] Donnet, J. B.; Bansal, R. C.; Wang, M. J. "Carbon black science and technology", 2nd ed., Dekker, New York, 1993.

[26] Schmidt, M. W. I.; Noack, A. G. Global Biogeochemical Cycles 2000, 14(3), 777.

[27] Goetz, A.; Focke, A. B.; Faessler, A. Physical Review 1932, 39(1), 168.

[28] Inagaki, S.; Hisiyama, Y. “New Carbon Materials (Japanese original title: ニューカーボン材料)”, Gihodoshuppan, Tokyo, 1994.

[29] Bourrat, X. "Sciences of Carbon Materials", ed. H. Marsh, F. Rodriguez-Reinoso, Universidad de Alicante, Alicante, $2000,1$.

[30] Sing, K. S. W.; Everett, D. H.; Haul, R. A. W.; Moscou, L.; Pierotti, R. A.; Rouquerol, J.; Siemieniewska, T. Pure \& Appl. Chem. 1985, 57 (4), 603.

[31] Y. Sanada, M. Suzuki, K. Fujimoto. "Active Carbon", Koudansha, Tokyo, 1992, 190.

[32] Mochida, I.; Yoon, S. H.; Korai, Y.; Kanno, K.; Sakai, Y.; Komatsu, M. Mesophase Pitch from Aromatic Hydrocarbons, "Sciences of Carbon Materials", ed. H. Marsh, F. Rodriguez-Reinoso, Universidad de Alicante, Alicante, 2000, 259.

[33] Oberlin, A. Carbon 1984, 22 (6), 521.

[34] Zuleta, M.; Bjornbom, P.; Lundblad, A. J. Electrochemical Society 2005, 152 (2), A270.

[35] Han, S.; Sohn, K.; Hyeon, T. Chemistry of Materials 2000, 12 (11), 3337.

[36] Morishita, T.; Soneda, Y.; Tsumura, T.; Inagaki, M. Carbon 2006, 44 (12), 2360.

[37] Oya, A.; Kasahara, N. Carbon 2000, 38 (8), 1141.

[38] Lim, S.; Hong, S. h.; Qiao, W.; Duayne Whitehurst, D.; Yoon, S. H.; Mochida, I.; An, B. et al. Carbon 2007, 45
(1), 173.

[39] Howard, J. B.; McKinnon, J. T.; Makarovsky, Y.; Lafleur, A. L.; Johnson, M. E. Nature 1991, 352 (6331), 139.

[40] Jang, J.; Oh, J. H. Advanced Materials 2004, 16 (18), 1650.

[41] Yumura, M. “The Science and Technology of Carbon Nanotubes", ed. K. Tanaka, T. Yamabe and K. Fukui, Elsevier Science, Oxford, 1999, 2.

[42] Lim, S.; Yoon, S. H.; Korai, Y.; Mochida, I. Carbon 2004, $42(8-9), 1765$.

[43] Lim, S.; Yoon, S. H.; Mochida, I. Carbon 2004, 42 (8-9), 1773.

[44] Oya, A.; Otani, S. Carbon 1979, 17 (2), 131.

[45] Katz, M. J. J. Physical Chemistry 1956, 60 (9), 1338.

[46] Mochida, I.; Fujimoto, K.; Oyama, T. "Chemistry and Physics of Carbon", Vol. 24, ed. P. A. Thrower, Marcel Dekker, New York, 1994, 111.

[47] Jenkins, G. M.; Kawamura, K. "Polymeric Carbons-Carbon Fibre, Glass, and Char", Cambridge University Press, Cambridge, 1976.

[48] Yoon, S. H.; Korai, Y.; Mochida, I. Carbon 1994, 32(6), 1182.

[49] Gregg, S. J.; Sing, K. S. W. “Adsorption, Surface Area and Porosity", 2nd ed., Academic press, London, 1982.

[50] Mitani, S.; Lee, S. I.; Saito, K.; Korai, Y.; Mochida, I. Electrochimica Acta 2006, 51 (25), 5487.

[51] Mitani, S.; Lee, S. I.; Saito, K.; Yoon, S. H.; Korai, Y.; Mochida, I. Carbon 2005, 43 (14), 2960.

[52] Kisamori, S.; Kuroda, K.; Kawano, S.; Mochida, I.; Matsumura, Y.; Yoshikawa, M. Energy \& Fuels 1994, 8 (6), 1337.

[53] Mochida, I.; Kuroda, K.; Kawano, S.; Matsumura, Y.; Yoshikawa, M. Fuel 1997, 76 (6), 533.

[54] Mochida, I.; Kuroda, K.; Kawano, S.; Matsumura, Y.; Yoshikawa, M.; Grulke, E.; Andrews, R. Fuel 1997, 76 (6), 537.

[55] Knoblauch, K.; Richter, E.; Juentgen, H. Fuel 1981, 60 (9), 832.

[56] Komatsubara, Y.; Tsuji, K.; Shiraishi, I.; Ida, S.; Mochida, I. J. Fuel Soc. Jpn. 1985, 64, 840.

[57] Mochida, I.; Hirayama, T.; Kisamori, S.; Kawano, S.; Fujitsu, H. Langmuir 1992, 8 (9), 2290.

[58] Mochida, I.; Kuroda, K.; Miyamoto, S.; Sotowa, C.; Korai, Y.; Kawano, S.; Sakanishi, K.; Yasutake, A.; Yoshikawa, M. Energy and Fuels 1997, 11 (2), 272.

[59] Mochida, I.; Ogaki, M.; Fujitsu, H.; Komatsubara, Y.; Ida, S. Fuel 1983, 62 (7), 867.

[60] Komatsubara, Y.; Ida, S.; Fujitsu, H.; Mochida, I. Fuel 1984, 63 (12), 1738.

[61] Mochida, I.; Kisamori, S.; Hironaka, M.; Kawano, S.; Matsumura, Y.; Yoshikawa, M. Energy \& Fuels 1994, 8 (6), 1341. 
[62] Mochida, I.; Kawano, S.; Kisamori, S.; Fujitsu, H.; Maeda, T. Carbon 1994, 32 (1), 175.

[63] Mochida, I.; Kawano, S.; Hironaka, M.; Yatsunami, S.; Korai, Y.; Matsumura, Y.; Yoshikawa, M. Energy \& Fuels 1995, 9 (4), 659.

[64] Shirahama, N.; Mochida, I.; Korai, Y.; Choi, K. H.; Enjoji, T.; Shimohara, T.; Yasutake, A. Applied Catalysis B: Environmental 2005, 57 (4), 237.

[65] Lim, S.; Yoon, S. H.; Shimizu, Y.; Jung, H.; Mochida, I. Langmuir 2004, 20 (13), 5559.

[66] Hokazono, H.; Lim, S.; Yoon, S.-H.; Mochida, I. Extended Abstracts of Carbon 2004, Brown University, Providence, RI, U.S.A., 2004, L003.

[67] Sakanishi, K.; Ohira, M.; Mochida, I.; Okazaki, H.; Soda, M. Bulletin of the Chemical Society of Japan 1989, 62 (12), 3994.

[68] Sakanishi, K.; Hasuo, H. U.; Mochida, I.; Okuma, O. Energy \& Fuels 1995, 9 (6), 995.

[69] Farag, H.; Whitehurst, D. D.; Mochida, I. Industrial and Engineering Chemistry Research 1998, 37 (9), 3533.

[70] Whitehurst, D. D.; Isoda, T.; Mochida, I. Advances in Catalysis 1998, 42, 345.

[71] Sakanishi, K.; Taniguchi, H.; Hasuo, H. U.; Mochida, I.
Industrial and Engineering Chemistry Research 1997, 36 (2), 306.

[72] Motoyama, Y.; Takasaki, M.; Higashi, K.; Yoon, S. H.; Mochida, I.; Nagashima, H. Chemistry Letters 2006, 35 (8), 876.

[73] Takasaki, M.; Motoyama, Y.; Yoon, S. H.; Mochida, I.; Nagashima, H. J. Organic Chemistry 2007, 72 (26), 10291.

[74] Yoon, S. H.; Lim, S.; Hong, S. H.; Qiao, W.; Whitehurst, D. D.; Mochida, I.; An, B. et al. Carbon 2005, 43 (9), 1828.

[75] Borup, R.; Meyers, J.; Pivovar, B.; Kim, Y. S.; Mukundan, R.; Garland, N.; Myers, D. et al. Chemical Reviews 2007, 107 (10), 3904.

[76] Tsuji, M.; Kubokawa, M.; Yano, R.; Miyamae, N.; Tsuji, T.; Jun, M. S.; Hong, S. et al. Langmuir 2007, 23 (2), 387.

[77] Zheng, J. S.; Zhang, X. S.; Li, P.; Zhou, X. G.; Yuan, W. K. Catalysis Today 2008, 131 (1-4), 270.

[78] Maldonado, S.; Stevenson, K. J. J. Physical Chemistry B 2005, 109 (10), 4707.

[79] Zhang, J.; Su, D.; Zhang, A.; Wang, D.; Schlogl, R.; Hebert, C. Angewandte Chemie - International Edition 2007, 46 (38), 7319. 